\title{
PEMIKIRAN ABDUL LATIEF MUCHTAR DAN PERUBAHAN SIKAP POLITIK PERSATUAN ISLAM TAHUN 1983-1997
}

\author{
Lukman Amin \\ SMA Darul Hikam, Kota Bandung \\ luq_dh@yahoo.com
}

Abstract: $\quad$ Changes that occurred in the leadership of A. Latief Muchtar does not change the identity of Persis as a whole. The exact identity that emerged from the 20s as a puritanical organization still appears in the leadership of A. Latief Muchtar with the changes that occurred as a result of the thinking and actions of leadership A. Latief Muchtar, also caused by the socio-political developments taking place in Indonesia. Exactly as one of the great organizations in Indonesia always maintain the repertoire of science ever composed by its predecessors such as A. Hassan, M. Natsir, Isa Anshary, K.H.E. Abdurrahman, Abdullah and also A. Latief Muchtar without abandoning the latest findings in the flow of thought and scientific methodology. All these relics will be very useful in providing the direction of the Indonesian nation forward and for the development of religious scholarship. Historians should continue to explore the treasures of Indonesian national figures such as A. Latief Muchtar who will be very useful for the progress of the nation. That thought will be a guide for the next young thinkers to love more of their own history. Historians must also display exemplary in every writing so that history is not just a writing without meaning, but capable of giving influence to the Indonesian nation that is currently unstable. History Teachers should be able to take the example of the existence of figures such as A. Latief Muchtar who became a teacher without the pamrih, also in every teaching and learning process teachers should always display exemplary figures of Indonesia, one of which is A. Latief Muchtar. Today the Indonesian nation has lost the example of previous heroes because the idol's position today for students is replaced by the role of pseudo-figures displayed by the mass media.

Abstrak: $\quad$ Perubahan yang terjadi dalam Persis masa kepemimpinan A. Latief Muchtar tidak merubah identitas Persis secara keseluruhan. Identitas Persis yang muncul dari sejak tahun 20-an sebagai sebuah organisasi puritan masih tampak pada kepemimpinan A. Latief Muchtar dengan perubahan-perubahan yang terjadi sebagai akibat dari pemikiran dan tindakan kepemimpinan A. Latief Muchtar, juga diakibatkan oleh perkembangan sosial politik yang terjadi di Indonesia. Persis hendaknya sebagai salah satu organisasi yang besar di Indonesia senantiasa memelihara khasanah keilmuan yang pernah disusun oleh para pendahulunya seperti A. Hassan, M. Natsir, Isa Anshary, K.H.E. Abdurrahman, Abdullah dan juga A. Latief Muchtar tanpa meninggalkan temuan-temuan terbaru dalam arus pemikiran dan metodologi keilmuan. Pemikiran tersebut akan menjadi pemandu bagi pemikir-pemikir muda selanjutnya sehingg lebih mencintai sejarahnya sendiri. Para sejarawan juga harus menampilkan teladan dalam setiap penulisannya agar sejarah bukan hanya sekedar tulisan tanpa makna, tetapi mampu memberikan pengaruh terhadap bangsa Indonesia yang hari ini sedang tidak stabil. Guru Sejarah hendaknya mampu mengambil teladan dari keberadaan tokoh seperti A. Latief Muchtar yang menjadi guru tanpa pamrih, juga dalam setiap proses belajar mengajar hendaknya guru selalu menampilkan tokoh-tokoh teladan Indonesia, salah satunya adalah A. Latief Muchtar. Hari ini bangsa Indonesia telah kehilangan teladan para pahlawan terdahulu karena posisi idola hari ini bagi siswa tergantikan dengan peran-peran tokoh semu yang ditampilkan media massa.

Kata Kunci: $\quad$ Abdul Latief Mochtar, Persatuan Islam, sikap politik

\section{PENDAHULUAN}

Dalam sejarah perkembangan Persatuan Islam (Persis), kepemimpinan Abdul Latief Muchtar (A. Latief Muchtar) dari tahun 1983 sampai 1997 banyak ditandai dengan terobosan dan hal-hal baru dalam kultur serta kebiasaan Persis. Keberadaan Persis yang sejak berdirinya pada tahun 1923 (Ricklefs, 1998: 268) terkenal sebagai organisasi dengan pendekatan dakwah keras dan dianggap sebagai organisasi puritan banyak dipengaruhi oleh

HISTORIA: Jurnal Pendidik dan Peneliti Sejarah, p-issn:2620-4789 | e-issn:2615-7993 
tokoh sentralnya A. Hassan yang berusaha keras untuk mengembalikan kaum muslimin kepada pimpinan Quran dan Sunnah, menghidupkan jiwa jihad dan ijtihad, membasmi bid'ah dan khurofat, takhayul, taqlid dan syirik (Stoddard, 1966: 315316). Perkembangan selanjutnya Persis mengalami perkembangan baru ketika di bawah kepemimpinan A. Latief Muchtar Persis berubah menjadi sebuah organisasi yang mengedepankan pola pendekatan keterbukaan, sekalipun tidak merubah puritanisme yang dimilikinya.

Gejala keterbukaan yang muncul dalam kultur Persis di bawah kepemimpinan A. Latief Muchtar sudah kelihatan sejak awal kepemimpinanya yaitu ketika pada tahun 1985 pemerintahan Orde Baru memberlakukan UU No. 8/1985 tentang penataan Partai Politik (Parpol) dan Organisasi Kemasyarakatan (Ormas) yang mengharuskan adanya asas tunggal. Kebijakan Persis selanjutnya dalam bidang organisasi tidak terlepas dari dominasi kepemimpinan politik Orde Baru terhadap seluruh kekuatan sosial politik di Indonesia. Sebelum diberlakukannya undang-undang tersebut, pada tahun 1983 pemerintah Orde Baru melalui Majelis Permusyawaratan Rakyat (MPR) mengeluarkan Tap MPR No. II/ MPR/ 1983 (Wildan, 2000: 186).

Kebijakan pemerintah yang mengharuskan penyamaan asas tersebut diberlakukan tatkala A. Latief Muchtar masih mencoba mencari bentuk kepemimpinannya di Persis yang belum terlalu lama sepeninggal K.H. Endang Abdurrahman (K.H.E. Abdurrahman). Selanjutnya, Persis merundingkan persoalan tersebut dengan tidak melalui muktamar ataupun perdebatan yang panjang di internal Persis sendiri.

Adapun pemikiran A. Latief Muchtar sendiri tentang penyikapan pemberlakuan undang-undang tersebut bisa terlihat dari gaya kepemimpinannya yang mengedepankan sikap akomodatif terhadap pemerintahan Orde Baru. Kebijakan Orde Baru tersebut telah ikut memberikan pengaruh terhadap eksistensi hampir seluruh organisasi baik sosial kemasyarakatan maupun politik di Indonesia. Dampak tersebut tidak terkecuali menimpa Persis. Sikap Persis pada masa kepemimpinan A. Latief Muchtar tersebut secara terbuka menerima Pancasila sebagai asas organisasi. Selanjutnya Qanun Asasi diubah pada tahun 1987 untuk memasukkan
Pancasila ke dalamnya (Wildan, 2000 : 195, Qanun Asasi dan Qanun Dakhili Persatuan Islam, 1987: 3-4).

Setelah A. Latief Muchtar berhasil menanggulangi kesulitan organisasi pada aspek ideologis, maka beliau untuk kemudian menggulirkan perubahan-perubahan dalam beberapa bidang yang terdapat dalam organisasi Persis. Visi pembaharuannya tersebut meliputi bidang jam'iyyah (organisasi), dakwah, pendidikan, ekonomi, pembangunan fisik, dan sikap sense of Crisis terhadap persoalan kaum muslimin dengan mengeluarkan berbagai macam pernyataan sikap atas keterpurukan Islam dan bangsa (Risalah No. 9 TH. XXXV, 1997 : 16).

Pada tahun 1990, dalam Muktamar Persis ke-10 di Pesantren Persis Tarogong Garut, secara terbuka Persis menghadirkan Menteri Agama Munawir Sadjali dan Menteri Dalam Negeri Rudini. Hal ini merupakan terobosan dan tindakan baru dalam sejarah Persis. Sebelum kepemimpinan A. Latief Muchtar, setiap muktamar Persis selalu tidak melibatkan pers dan pemerintah sehingga hanya internal Persis saja yang mengetahui perkembangan Persis.

Keterbukaan Persis dibawah kepemimpinan A. Latief Muchtar juga ditandai dengan penyusunan kurikulum perguruan tinggi Islam milik Persis yang telah memasukkan kurikulum Filsafat dan Sufisme sebagai bidang studinya. Menurut A. Latief Muchtar, kedua subjeck matter tersebut dimasukkan ke dalam salah satu mata kuliah Perguruan Tinggi Persis agar orang-orang Persis bisa menjatuhkan pilihan dan menetapkan hukumnya sesuai dengan apa yang dia ketahui secara mendalam. Ada kesungguhan untuk menerima kebenaran dan menolak kebatilan dengan alasan yang kuat dengan memakai metode argumentatif dan ilmiah. Hal ini juga dimaksudkan agar lebih dapat mencari persamaan dan titik temu dengan organisasi masyarakat (ormas) Islam lainnya serta dapat menghindari perbedaan-perbedaan yang tidak perlu. Dengan cara ini ummat Islam diharapkan dapat melangkah secara bersama dalam membangun aspek sosial keagamaan (Nurmalasari, $1998: 41)$.

Dalam segi keanggotaan, awalnya Persis hanya dianggap sebagai organisasi dengan cakupan lokal, tetapi pada saat kepemimpinan A. Latief Muchtar,

HISTORIA: Jurnal Pendidik dan Peneliti Sejarah, p-issn:2620-4789 | e-issn:2615-7993 
Persis sudah menjadi organisasi yang mempunyai cakupan nasional (Nurmalasari, 1998: 40). Bila pada awal keberadaannya Persis hanya memiliki tidak lebih dari 300 pengikut, bahkan Persis di bawah kepemimpinan K.H.E. Abdurrahman anggotanya semakin menyusut, maka pada tahun 1990, Persis memiliki 97 Pimpinan Cabang (PC) dengan 7.306 anggota, dan pada tahun 1995 meningkat dengan tajam menjadi 196 PC, 26 Pimpinan Daerah (PD), dan tiga Pimpinan Wilayah (PW) dengan 10.604 orang anggota yang tersebar di 14 propinsi di Indonesia (Wildan, 1997: 147).

Perkembangan kepemimpinan Persis di bawah A. Latief Muchtar seperti digambarkan di atas, akan menemui hal yang sama bila melihat kepemimpinan tokoh-tokoh Persis sebelumnya. Ketokohan A. Hassan dengan pemikiran pemurniaan fiqh ibadahnya telah mengantarkan kondisi Persis ke dalam perdebatan-perdebatan yang tidak biasa sekitar ritual ibadah, kepemimpinan Isa Anshary yang lebih menitik beratkan aspek politik telah mengantarkan Persis masuk ke dalam politik praktis bahkan beliau berencana untuk merubah Persis menjadi sebuah partai politik dengan nama Jama’ah Muslimin, begitupun dengan kepemimpinan E. Abdurrahman yang lebih konsolidatif secara internal mengakibatkan Persis seolah anti politik dan menutup diri.

Walaupun Persis sama sekali tidak memiliki tradisi ketokohan seperti pada organisasi tradisional yang berkembang pada paruh pertama abad ke 20, namun pengaruh seorang tokoh sentral dalam kepemimpinan organisasi Persis tidak bisa diabaikan. Persis yang sangat menentang taqlid, kadang terjebak dalam kepanutan terhadap tokoh kharismatik Persis sendiri. Setiap zaman dalam perjalanan sejarah Persis memang selalu terisi dengan tokoh-tokoh, baik itu berpengaruh atau tidak secara pemikiran, termasuk Persis di bawah kepemimpinan A. Latief Muchtar.

Selanjutnya, keterbukaan A. Latief Muchtar sangat terlihat tatkala beliau bersedia untuk dicalonkan dan akhirnya terpilih menjadi anggota Dewan Perwakilan Rakyat (DPR)/ Majelis Permusyawaratan Rakyat (MPR) RepublikIndonesia dari Partai Persatuan Pembangunan (PPP). Hal ini merupakan sesuatu yang sangat dihindari pada masa kepemimpinan E. Abdurrahman, sekalipun pernah terjadi pada masa kepemimpinan Isa Anshary. Walaupun anggota Persis secara organisatoris tidak diwajibkan untuk memilih PPP dalam pemilu tahun 1997, namun langkah A. Latief Muchtar telah membawa anggota Persis pada perubahan orientasi politik. Para anggota dipersilahkan untuk mendukung ataupun tidak mendukung kebijakan pimpinannya tersebut.

Latar belakang di atas telah memberikan inspirasi kepada penulis untuk mengkaji lebih dalam tentang permasalahan tersebut dengan judul penelitian Pengaruh Pemikiran Abdul Latief Muchtar Terhadap Perubahan Sikap Politik Persatuan Islam (Persis) Tahun 1983-1997. Masalah tersebut dirinci ke dalam beberapa pertanyaan penelitian berikut ini :

1. Bagaimanakah riwayat hidup A. Latief Muchtar?

2. Bagaimanakah pemikiran A. Latief Muchtar berkenaan dengan perkembangan politik Indonesia kurun tahun 1983 sampai 1997?

3. Bagaimanakah pengaruh pemikiran A. Latief Muchtar terhadap perubahan sikap politik Persatuan Islam (Persis) tahun 1983 sampai $1997 ?$

Kajian tesis Rahman (1999) merupakan kajian paling menyeluruh tentang A. Latief Muchtar. Isi dari kajian tersebut berisi tentang Persis, riwayat singkat dan respon A. Latief Muchtar terhadap kondisi Orde Baru. Kajian tersebut berisi penjelasan tentang A. Latief Muchtar sebagai salah seorang tokoh Islam yang memberikan respon terhadap kehidupan Orde Baru. Bab kesatu kajian tersebut berisikan tentang kondisi keislaman Indonesia dan awal mula Persis berdiri serta penjelasan tentang beberapa tokoh terkenal Persis sebelum kepemimpinan A. Latief Muchtar. Bab kedua berisikan tentang riwayat hidup A. Latief Muchtar, terdiri dari kehidupan keluarga, riwayat pendidikan, kepribadian, karir dan aktifitas publikasi. Bab ketiga berisikan ide-ide A. Latief Muchtar dan aktifitasnya yang terdiri dari respon terhadap sejarah Islam, respon terhadap dunia muslim dan respon terhadap kehidupan masyarakat Indonesia.

Hal yang terungkap dari kajian tersebut berkenaan dengan A. Latief Muchtar salah satunya yaitu tentang kepribadiannya. Rahman (1999 : 4448) mengatakan bahwa A. Latief Muchtar adalah seorang tokoh yang populer, kharismatik tapi 
tetap tawadlu (rendah hati). Kemudian Rahman mengutip pendapat Anwar Haryono tentang A. Latief Muchtar yang memberikan sebuah ilustrasi kondisi tersebut, seperti padi yang semakin berisi akan semakin merunduk.

A. Latief Muchtar sangat menyukai diskusi sehingga dalam mengupayakan perluasan pendapatnya beliau selalu mendahulukan dialog kepada siapa saja, termasuk kepada orang dengan karakter keras. Hal tersebut juga terjadi selama beliau mengajar. A. Latief Muchtar selalu berupaya untuk belajar, bahkan dari muridnya. Beliau tidak memandang posisi guru sebagai sosok yang tahu akan segalanya, tetapi A. Latief Muchtar mampu memposisikan diri sebagai seorang guru pembelajar dengan mengajak murid-muridnya sebagai teman diskusi.

Dalam kehidupan sosial, A. Latief Muchtar juga merupakan seorang yang sangat dermawan kepada fakir miskin. Beliau selalu ingin membantu orang-orang yang kekurangan pada aspek finansial. Berbeda dengan tokoh ulama pendahulunya di Persis, A. Latief Muchtar sangat akrab dengan ulamaulama Nahdhatul Ulama (NU), sebuah organisasi yang sering diasosiasikan sebagai lawan Persis. A. Latief Muchtar selalu mengedepankan pendekatan lembut dengan membangun hubungan yang baik antar organisasi sekalipun dengan organisasi yang dianggap bersebrangan seperti NU.

Kajian lain tentang A. Latief Muchtar juga dilakukan oleh Nurmalasari (1997: 39). Dalam kajiannya tersebut Nurmalasari membahas kepemimpinan A. Latief Muchtar yang ditandai dengan keterbukaan. Gejala-gejala keterbukaan tersebut menurutnya ditandai dengan beberapa kebijakan kepemimpinan A. Latief Muchtar yang mencakup, Pertama, pendekatan kuantitas tanpa menyepelekan kualitas pada masa kepemimpinan A. Latief Muchtar mengakibatkan pemahaman keislaman anggota Persis yang semakin beragam. Kedua, penyusunan kurikulum Perguruan Tinggi Persis yang didirikan pada masa kepemimpinan A. Latief Muchtar telah memasukkan Filsafat dan Sufisme sebagai salah satu mata kuliahnya. Ketiga, Persis merupakan ormas yang paling pertama mendukung hari teknologi nasional yang dicanangkan pemerintah melalui Menteri Riset dan Teknologi (Menristek) Baharudin Jusuf Habibi (B.J.
Habibi). Keempat, A. Latief Muchtar terkenal sebagai tokoh yang akrab dengan KH. Jusuf Hasjim, salah seorang tokoh NU. Sebelum kepemimpinan beliau, hal ini sangat jarang terjadi. Kelima, pada muktamar ke-10 di Pesantren Persis Tarogong Garut, Persis menghadirkan pihak pemerintahan. Perubahanperubahan tersebut, menurut Nurmalasari bisa terlihat dalam Qanun Asasi dan Qanun Dakhili yang mengalami perubahan.

Kajian Wildan (1997) salah satu bahasannya menyangkut A. Latief Muchtar. Setelah menjelaskan riwayat singkat tentang A. Latief Muchtar, dalam bahasa yang lain Wildan (1997: 141) mengatakan bahwa A. Latief Muchtar merupakan seorang sosok pembaharu Persis. Pada awal kepemimpinan, A. Latief Muchtar secara rendah hati, mengatakan bahwa kepemimpinan dalam Persis bagi dirinya hanya melanjutkan program K.H.E. Abdurrahman, Ketua Umum Persis sebelumnya, namun dalam perkembangan selanjutnya, A. Latief Muchtar membawa Persis pada arah perkembangan baru.

Dalam kajian tersebut Wildan (1997 : 145-146) menulis bahwa hal pertama yang dihadapi oleh A. Latief Muchtar dalam masa kepemimpinannya adalah permasalahan ideologi yaitu berkenaan dengandiberlakukannyaUU.No8tahun 1985.Dalam menghadapi permasalahan ini, A. Latief Muchtar mampu melewatinya dengan baik. Setelah itu, dalam memimpin Persis A. Latief Muchtar bertekad untuk menjadikan Persis sebagai organisasi yang mandiri, tanpa mengisolir diri, Persis tidak mengikatkan diri pada kekuatan lain meskipun ia membuka diri. Tidak hanya itu, dalam kepemimpinannya, beliau berkeinginan untuk meningkatkan kualitas organisasi yang dipimpinnya melalui pendekatan persuasif. Berawal dari pemikiran dan keinginannya tersebut, melalui sentuhan A. Latief Muchtar Persis tidak lagi mengisolir diri dari berbagai persoalan ummat. Keterbukaan ini yang tampaknya telah meningkatkan anggota Persis secara kuantitas.

Dalam bidang dakwah, A. Latief Muchtar memberikan warna baru terhadap dinamika peta dakwah di Indonesia. Persis tidak lagi berdakwah dengan gebrakan-gebrakan shock Therapy tetapi melalui pendekatan persuasif edukatif. Persis kini tampil untuk mencari jelas, bukan mencari puas. Dalam kepemimpinannya pula, Persis mulai merambah dunia kampus dengan mendirikan HISTORIA: Jurnal Pendidik dan Peneliti Sejarah, p-issn:2620-4789 | e-issn:2615-7993 
salah satu organisasi otonom baru Persis, yaitu Himpunan Mahasiswa Persatuan Islam (Hima Persis) dan Himpunan Mahasiswi Persatuan Islam (Himi Persis).

Dalam bidang ekonomi, A. Latief Muchtar merupakan penggagas berdirinya Bank Pengkreditan Rakyat (BPR) dalam tubuh Persis sebagai suatu bentuk bank Islam tanpa bunga. Beliau duduk sebagai komisaris BPR Amanah Robbaniyyah yang menerapkan sistem bank tanpa bunga tersebut. Langkah ini ditempuh sebagai salah satu upaya untuk menghindarkan diri dari sikap sekuler.

Dalam bidang pendidikan, A. Latief Muchtar menginginkan kader-kader ulama Persis yang handal dengan berusahakeras meningkatkan jenjang pendidikan yang ada di lingkungan Persis. Tidak hanya pada pendidikan dasar dan menengah, tetapi A. Latief Muchtar juga menjadi pendiri Perguruan Tinggi Persis yang disebut dengan Pesantren Luhur pada tahun 1988. Dalam perkembangan selanjutnya Perguruan Tinggi ini terus berbenah dan berubah nama. Ide besarnya tentang Pendidikan Tinggi bahkan tercetus tiga pekan sebelum beliau wafat. A. Latief Muchtar sempat membicarakan pendirian Universitas Ahmad Hassan, sebuah Universits Persis yang berbasis agama dan pengembangan teknologi dengan terlebih dahulu mendirikan Sekolah Tinggi Teknologi Mutu (STTM) Ahmad Hassan.

Pada masa kepemimpinan A. Latief Muchtar dalam Persis, kelebihan lain yang dimiliki beliau adalah jaringan internasional yang dimilikinya. Kiprahnya di dunia internasional merupakan ungkapan ukhuwwah dan solidaritas, baik melalui Organisasi Konferensi Islam (OKI), Rabithah 'Alam Islami (Moslem World League) maupun pertemuanpertemuan informal tokoh-tokoh Islam dunia.

Selanjutnya, menurut Wildan (1997: 150-151) kondisi sosial politik pada tahun 1997 menjadikan A. Latief Muchtar bersedia menjadi calon anggota DPR/ MPR RI dari PPP, namun sebelum beliau melakukan cita-citanya tersebut, A. Latief Muchtar wafat pada hari senin tanggal 13 Oktober 1997 di Rumah Sakit Pusat Angkatan Darat (RSPAD) Gatot Subroto Jakarta. Pilihan A. Latief Muchtar menjadi politikus dari PPP sebagai upaya untuk memperluas cakupan dakwah dan mencoba mencari jalan

\section{lain dalam mengupayakan proses Islamisasi di} Indonesia.

Dalam kajian ini, pembahasan tentang A. Latief Muchtar diakhiri dengan pesan terakhir A. Latief Muchtar untuk seluruh anggota, simpatisan Persis dan masyarakat serta pemerintahan. Isi pesan tersebut berkenaan dengan apa yang selama beliau hidup diperjuangkannya yaitu pendekatan yang luwes dalam berdakwah bagi para anggota, ajakan untuk tidak curiga terhadap Persis yang ditujukan kepada masyarakat dan pemerintah.

Kajian lain Wildan (2000: 192-196) membahas tentang A. Latief Muchtar sebagai bagian dari pembahasannya tentang Persis secara keseluruhan. Dalam buku ini diungkap perubahan sikap politik Persis pada saat pemberlakuan asas tunggal. Terdapat banyak alasan penerimaan sikap Persis terhadap penerapan asas tunggal, diantaranya, Pertama, pilihan menolak dan menerima Pancasila adalah dua pilihan yang kedua-duanya membawa madharat. Oleh karena itu Persis memutuskan untuk memilih salah satu yang madharatnya lebih sedikit. Berpijak dari ketentuan ini, Persis kemudian mengambil ketentuan fiqh bahwa dalam Islam dikenal adanya kebolehan untuk keluar dari suatu kaidah dasar sepanjang didasarkan pada pertimbangan-pertimbangan tertentu yang mendesak.

Alasan kedua dari perubahan sikap politik Persis muncul dari sebuah pertanyaan "akan dikemanakan tanah-tanah wakaf yang telah diamanatkan ummat, mesjid-mesjid yang selama ini telah dikelola secara rapi, dan lembaga-lembaga pendidikan yang telah tersebar sedemikian banyak". Ternyata tidak ada satupun pimpinan Persis yang mampu memberikan jawaban yang tepat terhadap pertanyaan tersebut.

Alasan-alasan di atas telah mendorong Persis merubah asas organisasi menjadi Pancasila, namun hal yang belum jelas dalam buku ini, bahwa Wildan tidak menjelaskan secara lebih detail peranan yang telah diambil oleh A. Latief Muchtar selama perubahan-perubahan tersebut. Buku ini hanya menjelaskan tentang Persis secara keseluruhan. Ketokohan dan peranan A. Latief Muchtar dalam proses perubahan tersebut sama sekali tidak dijelaskan. 
Kajian Alimurrohman (1998) menitikberatkam kepada kontribusi pemikiran A. Latief Muchtar terhadap pembangunan perekonomian ummat dalam Program Kerja Persis Tahun 1995-1997. Alimurrohman mengatakan bahwa pemikiran A. Latief Muchtar dalam pengembangan ekonomi sangat berpengaruh terhadap program kerja yang dijalankan oleh Persis dalam bidang ekonomi yakni dengan didirikannya BPR yang tidak menggunakan bunga.

Buku selanjutnya merupakan kumpulan tulisan-tulisan A. Latief Muchtar (Cuanda dan Rakhmat: 1998). Buku ini diawali isi surat dari Isa Anshary untuk A. Latief Muchtar ketika sedang menuntut ilmu di Mesir serta sambutan dari beberapa rekannya sesama tokoh Islam Indonesia, baik dari kalangan Persis maupun dari luar Persis. Beberapa tokoh tersebut antara lain, M. Amin Rais, Jalaludin Rakhmat, Anwar Harjono, M. Rusyad Nurdin, Tarmizi Taher, Afif Muhamad, Zuhal Abdul Qadir, A.M Luthfi, Shiddiq Amin dan perwakilan dari keluarganya Ihsan Setiadi Latief. Sambutan tersebut berkisar tentang kepribadian, intelektual, keberhasilan serta pertentangan yang terjadi antara A. Latief Muchtar dengan tokoh-tokoh tersebut.

Amin Rais berpendapat bahwa terdapat tiga hal yang menonjol dari A. Latief Muchtar. Pertama, kerendahan hati sebagi seorang alim. Kedua, kesederhanaan. Ketiga, Kecintaan pada ummat yang dipimpinnya. Amin Rais selanjutnya mengatakan bahwa gelombang atau frekwensi kejiwaan Persis tidaklah berbeda dengan organisasi yang dipimpinnya, Muhammadiyyah (Rais, 1998: $\mathrm{x})$.

Keseluruhan kajian di atas, ternyata belum ada yang secara khusus membahas tentang pemikiran A. Latief Muchtar bila dihubungkan dengan perubahan sikap politik Persis. Hampir secara keseluruhan, pembahasan tentang A. Latief Muchtar disatukan dengan pembahasan tentang Persis secara keseluruhan. Pembahasan tentang A. Latief Muchtar dalam beberapa kajian di atas merupakan sesuatu yang sangat wajar karena Persis pernah di bawah kepemimpinan A. Latief Muchtar pada tahun 1983 sampai tahun 1997. Kajian di atas juga hanya mengungkap hal-hal positif dari kepemimpinan A. Latief Muchtar dalam persis, bahkan kadang terkesan terlalu berlebihan, padahal sebagai seorang manusia, A. Latief Muchtar tidak akan pernah melakukan kebenaran terus-menerus.

Sepanjang pengetahuan penulis, para peneliti ataupun sejarawan belum banyak melakukan kajiankajian tentang A. Latief Muchtar. Sampai tulisan ini disusun, karya tentang A. Latief Muchtar baik secara pemikiran maupun kepemimpinannya dalam Persis hanya terdapat dalam beberapa buku, beberapa penelitian penelitian dan sebuah penelitian tesis. Hampir keseluruhan penelitian tersebut tidak secara langsung membahas tentang A. Latief Muchtar, tetapi pembahasan tentang A. Latief Muchtar hanya sebagai ketua umum Persis dalam salah satu bagian dari tulisan tersebut. Hanya ada satu penelitian yang mengkhususkan penelitiannya tentang A. Latief Muchtar yaitu penelitian tesis Rahman (1999), tetapi kajian tersebut tidak membahas pengaruh pemikiran A. Latief Muchtar terhadap perubahan sikap politik Persis.

\section{METODE PENELITIAN}

Penelitian ini menggunakan metode historis. Pertimbangan penulis menggunakan metode historis dalam penulisan ini karena data dan fakta yang dikumpulkan dalam rangka penyusunan tulisan ini berasal dari masa lampau. Adapun pendekatan yang digunakan dalam penulisan penelitian ini adalah pendekatan Studi Biografi. Untuk lebih mensistematiskan penelitian dalam pelaksanaan penelitian tulisan ini, penulis menggunakan metode penelitian sejarah dengan memperhatikan tahapan-tahapan berikut ini :

Heuristik, proses mengumpulkan sumbersumber kepustakaan yang penulis peroleh dari berbagai perpustakaan, diantaranya adalah perpustakaan Universitas Pendidikan Indonesia (UPI), perpustakaan Institut Agama Islam Negeri (IAIN) Sunan Gunung Djati Bandung, perpustakaan Universitas Padjadjaran (Unpad), perpustakaan ABRI, perpustakaan daerah Jawa Barat, koleksi pribadi penulis, koleksi keluarga besar A. Latief Muchtar dan koleksi beberapa peneliti sejarah lainnya. Kedua, yaitu dengan melakukan pencarian data dan arsip pribadi dan tulisan-tulisan lepas A. Latief Muchtar yang belum sempat terpublikasikan, juga majalah yang pernah mempublikasikan tulisan A. Latief Muchtar. Tulisan tersebut penulis dapatkan

HISTORIA: Jurnal Pendidik dan Peneliti Sejarah, p-issn:2620-4789 | e-issn:2615-7993 
dari beberapa tempat yang mampu memberikan informasi tentang tokoh A. Latief Muchtar dan segala pemikirannya. Tempat tersebut antara lain kantor Pimpinan Pusat (PP) Persatuan Islam, rumah kediaman A. Latief Muchtar dan beberapa sanak keluarganya serta kantor majalah Risalah. Ketiga yaitu dengan melakukan wawancara terhadap beberapa tokoh yang sezaman dengan A. Latief Muchtar dan mengetahui proses kepemimpinan A. Latief Muchtar dalam Persis. Penggunaan metode wawancara penulis pergunakan berdasarkan sebuah asumsi bahwa orang-orang yang mengetahui sekaligus melakukan perjuangan bersama A. Latief Muchtar masih hidup dan bisa memberikan informasi tentang kajian yang penulis susun dalam penelitian ini.

Adapun narasumber yang penulis wawancara dalam penulisan penelitian ini adalah sebagai berikut :

1. Aking Setiawan (Sekretaris Umum Pusat Pimpinan Persatuan Islam tahun 1981-1990)

2. Emon Sastranegara (Sekretaris Umum Pusat Pimpinan Persatuan Islam tahun 1990-2000)

3. Toha Kahfi (Ketua Bidang Garapan Perwakafan Pusat Pimpinan Persatuan Islam tahun 19801990)

4. Ihsan Setiadi Latief (anak A. Latief Muchtar)

5. Yusuf Amir Faisal (adik A. Latief Muchtar)

6. Juju Juhari (teman kecil A. Latief Muchtar)

Beberapa tulisan tentang A. Latief Muchtar penulis bandingkan dengan dokumen asli milik keluarga serta PP Persis. Kritik eksternal penulis meneliti kelayakan informasi wawancara dengan menyertakan pertanyaan berikut ini, Siapa yang mengatakan itu, Apakah dengan satu atau cara lain kesaksian itu telah diubah, Apakah sebenarnya yang dimaksud orang itu melalui kesaksiannya tersebut, Apakah yang memberikan kesaksian itu seorang saksi mata yang terlibat dan mengetahui fakta itu, Apakah orang tersebut memberikan informasi dengan sebenarnya. Pertanyaan-pertanyaan di atas penulis jawab dengan meneliti jejak sejarah yang pernah narasumber tempuh selama memiliki keterhubungan dengan A. Latief Muchtar. Berkaitan dengan dokumen, kritik eksternal dilakukan dengan meneliti keaslian dokumen tersebut.

Interpretasi, yaitu menafsirkan keterangan dari sumber-sumber sejarah berupa fakta yang terkumpul dengan cara dirangkai dan dihubungkan sehingga tercipta penafsiran sumber sejarah yang relevan dengan permasalahan.

Data dan fakta yang ditafsirkan adalah sumber yang sudah melalui tahapan kritik. Penulis menggabungkan sumber yang telah didapatkan dari buku-buku, dokumen dan wawancara. Hal ini dilakukan agar hasil interpretasi merupakan sebuah rangkaian yang selaras, tidak ada pertentangan antara sumber-sumber yang sudah didapatkan. Tidak jarang, keterangan narasumber sangat bertolak belakang dengan yang penulis dapatkan dalam buku maupun dokumen. Hal ini penulis maklumi karena narasumber yang diwawancara sebagian besar telah memasuki usia senja Dalam interpretasi, penulis menggunakan daya imajinasi dan subjektifitas penulis yang dapat dipertanggungjawabkan berdasarkan fakta yang sudah ada.

Historiografi, merupakan suatu kisah masa lampau yang direkonstruksi oleh sejarawan berdasarkan fakta yang ada (Hariyono, 1995 : 102). Historiografi juga diartikan sebagai proses yang dilakukan apabila sumber-sumber sejarah yang ditemukan, dianalisis dan ditafsirkan telah rampung, kemudian sumber-sumber tersebut ditulis menjadi suatu kisah sejarah atau cerita ilmiah yang selaras dengan fakta-fakta yang telah ditemukan dengan tujuan mengkomunikasikan hasil penelitian atau temuan kepada umum sehingga temuan tersebut tidak saja memperkaya wawasan diri sendiri melainkan juga dapat memberikan sumbangan ilmu bagi khalayak umum.

Pendekatan biografi yang digunakan penulis dalam penyusunan penelitian sangat berpengaruh dalam historiografi kajian ini. Penulisan penelitian ini mencoba untuk memenuhi ketentuan sebuah biografi yang scientific dengan menggunakan fakta valid dan penulisan analisis ilmiah. Disamping itu, dalam penulisannya, penulis mencoba menuliskan tentang pemikiran A. Latief Muchtar dengan memiliki empat ketentuan berikut, yaitu (1) kepribadian tokohnya, (2) kekuatan sosial yang mendukung, (3) lukisan sejarah zamannya, dan (4) keberutungan dan kesempatan yang datang (Kuntowijoyo, $2003: 206$ ). 


\section{PEMBAHASAN}

\section{Riwayat Hidup A. Latief Muchtar}

A. Latief Muchtar lahir di Garut pada tanggal 7 Januari 1931 dalam keluarga pedagang yang cukup berhasil namun tetap hidup sederhana. Ayahnya bernama $\mathrm{H}$. Muchtar merupakan seorang pedagang tembakau, yang juga berprofesi sebagai pendakwah. Sebelum beliau berdagang, biasanya H. Muchtar berdakwah terlebih dahulu. Hal ini hampir sama dengan pengemban Persis pada awal sejarahnya yang kebanyakan merupakan para pedagang sukses dari Sumatera.

Dalam kehidupannya, H. Muchtar merupakan salah seorang yang terlibat dalam dunia aktifitas pergerakan keislaman. Beliau sangat akrab dengan tokoh-tokoh Darul Islam (DI) di Garut. H Muchtar mengenal beberapa tokoh DI, salah satunya adalah Kartosuwiryo. Bahkan H Muchtar sempat memberikan pendapat kepada Kartosuwiryo untuk tidak menyingkir ke pegunungan tatkala DI tersudutkan karena akan diberlakukan pagar betis oleh pemerintah. Pada masa ini, Persatuan Islam tidak mendukung perjuangan DI karena peranan M. Natsir yang hendak berjuang melalui parlemen (Latief : 30/05/2005). H. Muchtar meninggal pada tahun 1960 ketika A. Latief Muchtar masih belajar di Mesir (Rahman, 1999: 40).

Kesempatan H. Muchtar untuk terlibat dengan tokoh-tokoh pemikir politik Islam telah membentuk pemikiran keislamannya yang progresif. Hal tersebut mampu memberikan pengaruh terhadap perkembangan pemikiran A. Latief Muchtar yang sejak kecil telah mengenal pemikiran-pemikiran baru dalam Islam. Proses keterbukaan pemikiran A. Latief Muchtar juga dipengaruhi oleh pola pendidikan penerapan ayahnya yang merupakan seorang pedagang. Pola pikir pedagang yang terbuka dengan perkembangan baru menjadikan A. Latief Muchtar dari sejak kecil telah mengenal halhal baru sehingga tidak terjebak tradisionalisme yang mengungkung kehidupan beragama.

Ibunda A. Latief Muchtar bernama $\mathrm{Hj}$. Memeh merupakan seorang ibu rumah tangga sekaligus pedagang yang tidak terlalu aktif dalam dunia keislaman. Beliau lebih berkonsentrasi untuk menjadi seorang ibu rumah tangga sekaligus pedagang nasi di sekitar Cihampelas dan membesarkan putra-putranya dengan baik. Perjuangan dalam kontribusi keislaman beliau hanya berlangsung di balik layar dengan menemani suaminya dalam berjuang. Menurut putra A. Latief Muchtar, Ihsan Setiadi Latief, Walaupun sebagai istri neneknya dimadu oleh $\mathrm{H}$ Muchtar, namun beliau sangat akrab dengan tiga istri $\mathrm{H}$ Muchtar lainnya (Latief : 30/05/2005, Feisal : 03/06/2005, Wildan : 141). Hj Memeh meninggal dunia pada tahun 1989 (Rahman : 1999 : 40).

A. Latief Muchtar memiliki lima saudara. Dua di antara saudaranya berbeda ibu dengan A. Latief Muchtar. Saudara A. Latief Muchtar yang sebapak dan seibu adalah Eman Suleman, Emen dan Fatimah (Iting) sedangkan saudara berbeda ibu yaitu Jajang dan Yusuf Amir Feisal, mantan wakil ketua Majelis Permusyawaratan Rakyat (MPR) Indonesia dari 1999 sampai 2004 (Feisal : 03/06/2005).

Kedua orang tua A. Latief Muchtar yang merupakan pedagang tembakau dan warung nasi telah memberikan pengaruh terhadap perkembangan pemikiran A. Latief Muchtar. Pertama, Kehidupan sederhana yang tercermin dalam kehidupan A. Latief Muchtar merupakan pengaruh $\mathrm{Hj}$. Memeh sebagai seorang ibu yang telah mendidik anak-anaknya dengan pendekatan para pedagang. Pemikiran-pemikiran A. Latief Muchtar banyak menyentuh hal-hal yang sederhana dan berkaitan dengan ummat Islam yang masih dalam keadaan miskin, jika pengaruh tersebut berlangsung, maka sangat wajar salah satu putranya mengatakan bahwa A. Latief Muchtar sangat terkenal egaliter dan sederhana dalam kehidupannya. Hal ini berbeda dengan Yusuf Amir Feisal sebagai saudaranya yang terkesan berkelas (Latief : 30/05/2005). Pemikiran A. Latief Muchtar tentang cita ideal Islam diawali dari proses pembaharuan yang beliau lakukan dalam tubuh Persis, baru kemudian beliau berfikir dan bertindak untuk Islam secara lebih luas dengan menggabungkan diri bersama Partai Persatuan Pembangunan (PPP). Kedua, pemikiran moderat dan demokratis yang A. Latief Muchtar kembangkan, baik dalam mendidik keluarga, dakwah dan pengembangkan Persis merupakan pengaruh dari orang tua A. Latief Muchtar yang mengembangkan pendekatan dialogis dalam memberikan didikan. Ihsan Setiadi Latief menganggap bahwa ayahnya

HISTORIA: Jurnal Pendidik dan Peneliti Sejarah, p-issn:2620-4789 | e-issn:2615-7993 
tersebut kadang juga berperan sebagai seorang sahabat karena selalu mengajak berdialog tatkala A. Latief Muchtar memiliki permasalahan. Selama A. Latief Muchtar menjalankan fungsi sebagai da'i, beliau selalu menggunakan pendekatan persuasif dan dialogis, A. Latief Muchtar selalu bersedia tatkala yang mengundang beliau adalah kalangan mahasiswa. Persis di bawah kepemimpinan A. Latief Muchtar juga ditandai pengoptimalan fungsi Dewan Hisbah sebagai tempat pengkajian hukum Islam dan dibentuknya Dewan Tafkir Persis sebagai tempat pengkajian pemikiran kontemporer baik keislaman maupun aspek kehidupan lainnya. Perkembangan ini telah membawa Persis memiliki tampilan lain dalam perjalanannya membawa pembaharuan Islam di Indonesia.

Satu hal lain yang juga mempengaruhi pola pemikiran A. Latief Muchtar adalah kerukunan beberapa istri ayahnya yang lebih dari dua istri. Kerukunan ini terlihat berpengaruh tatkala A. Latief Muchtar memberikan pemecahan terhadap permasalahan yang muncul dalam keluarga, dakwah dan Persis. Aisyah Wargadinata sebagai istrinya mengaku pernah memprotes A. Latief Muchtar karena terlalu banyak berdiskusi dan menghabiskan waktu panjang, tetapi A. Latief Muchtar menjawab dengan sabar keluhan istrinya tersebut. Pada majalah Risalah, A. Latief Muchtar pernah berpolemik tajam dengan Jalaludin Rakhmat perihal Syiah yang menurut A. Latief Muchtar merupakan ajaran sesat dan menyimpang dari Islam, tetapi dalam persahabatan, A. Latief Muchtar adalah juga sahabat baik untuk Jalaludin Rakhmat.

Pada masa kepemimpinan A. Latief Muchtar, Persis menerima Pancasila sebagai sebuah asas organisasi dengan pendekatan yang baik dengan cara menerima masukan dari anggota sehingga Persis mampu bekerja sama dengan pemerintah. Seluruh tindakan A. Latief Muchtar selalu tidak memandang orang yang berbeda sebagai musuh yang harus dilawan, tetapi menjadi arena untuk mencari jelas, bukan hanya mencari puas.

A. Latief Muchtar tumbuh dalam kehidupan dan didikan ayahnya yang religius (Wildan, 1997: 141). A. Latief Muchtar yang ketika kecil sering dipanggil Atief dalam kesehariannya telah dididik untuk menjadi seorang muslim yang taat. Sejak kecil A. Latief Muchtar terkenal sebagai anak yang cerdas (Juhari : 17/04/2005). Sebagai seorang kakak, menurut Yusuf Amir Feisal, A. Latief Muchtar selalu menjadi pelindung bagi dirinya. Tidak heran jika mereka sedang bermain di sungai Cikapundung yang pada saat itu masih bisa dipakai untuk berenang karena kejernihannya, A. Latief Muchtar menggendong Yusuf Amir Feisal agar adiknya tersebut terlindungi, begitupun ketika mereka berdua sedang bermain bola, kebiasaan A. Latief Muchtar adalah melindungi adiknya tersebut.

Sifat melindungi terhadap adiknya, terbawa juga dalam corak pemikiran A. Latief Muchtar yang banyak berupaya untuk memberikan layanan terbaik untuk para anggota Persis. Selama kepemimpinannya dalam Persis, A. Latief Muchtar berjuang untuk menjadi penyambung para anggota Persis dengan kebutuhan yang dirasakan mereka. Para anggota Persis yang banyak berasal dari keluarga pra sejahtera mengilhami A. Latief Muchtar menjadikan aspek ekonomi menjadi program jihad baru dalam Persis dengan mendirikan Bank Pengkreditan Rakyat (BPR) non ribawi, selain itu juga keberangkatan beberapa alumni pesantren Persis yang berhasil mengenyam beasiswa pendidikan di Timur Tengah berkat peranan A. Latief Muchtar yang memiliki jaringan internasional merupakan bagian dari keinginan melindungi dan memajukan para anggota Persis.

Riwayat pendidikan A. Latief Muchtar diawali pada saat A. Latief Muchtar kecil berumur enam tahun dengan memasuki jenjang pendidikan di Pendidikan Islam (Pendis) yang didirikan oleh Persis di bawah bimbingan M. Natsir. Setelah menamatkan pendidikan awalnya tersebut kemudian beliau memasuki pesantren Persis yang baru berdiri pada tanggal 4 Maret 1936 sebagai pengganti Pendis. A. Latief Muchtar pertama kali masuk jenjang Ibtidaiyyah di bawah bimbingan Ustadz Abdurrahman, Ustadz Sudibya dan Ustadz Komaruddin Saleh (Rahman, 1999: 42).

Proses pendidikan awal yang A. Latief Muctar terima telah ikut memberikan masukan pemikiran gerakan pembaharuan Islam ke dalam Persis yang berusaha mengembalikan umat kepada Quran dan sunnah tatkala A. Latief Muchtar menjabat sebagai ketua umum Persis sejak tahun 1983 sampai 1997 (Feisal, 03/06/2005). Pendidikan yang diterima A. Latief Muchtar dari pendidikan formal Persis telah 
menjadikan beliau mengenal keterbukaan dengan segala perubahan dari sejak usia dini. Ajaran Persis pada saat A. Latief Muchtar menjalani kehidupan kecil tergolong aneh di masyarakat. Banyak dari masyarakat yang memandang Persis merupakan agama baru, namun kondisi ini tidak menyurutkan orang tua A. Latief Muchtar untuk mendidik anakanaknya dengan ajaran Persis.

Setelah A. Latief Muchtar menamatkan Ibtidaiyyah, kemudian beliau memasuki jenjang Tsanawiyyah dan Muallimin, dua tingkat pendidikan sekolah yang setara dengan Sekolah Menengah Pertama (SMP) dan Sekolah Menengah Atas (SMA). Sebagai seorang putra dari kalangan Persis, A. Latief Muchtar memasuki semua jenjang pendidikan yang dibuka Persis. Beliau menamatkan Pendidikan Dasar, Menengah Pertama dan Menengah Atas pada lembaga Pendidikan Persis pada tahun 1952.

Pada masa yang bersamaan dengan pendidikannya tersebut, beliau pernah menjadi santri masa revolusi di tempat pengungsian di daerah Gunung Cupu Ciamis Jawa Barat di bawah bimbingan Ustadz Abdurrahman. Beliau juga pernah mengenyam pendidikan di Pesantren Darul Latief Garut. Ketika belajar di Pesantren Persis A. Latief Muchtar mengikuti ujian persamaan tingkat SMP di SMP Muhammadiyah. Karena itu beliau dapat masuk ke SMA Belitung atau sekarang lebih dikenal dengan SMAN 3 Bandung. Pendidikan formal di dua sekolah tersebut beliau mampu selesaikan pada tahun 1953 (Rahman, 1999: 42). Pendidikan dua sekolah yang dilakukan A. Latief Muchtar telah memberikan pengaruh terhadap arah dan corak pemikiran A. Latief Muchtar yang sangat toleran dan moderat.

Pada saat beliau tercatat sebagai santri di Pesantren Persis, beliau merupakan salah seorang siswa yang aktif sehingga mengantarkan A. Latief Muchtar menjadi salah seorang ketua Rijalul Ghad (RG), sebuah organisasi intra sekolah khusus santri putra pesantren Persis dari tahun 1951 sampai tahun 1952. Keterlibatannya dalam organisasi pada usia muda telah mengantarkan A. Latief Muchtar menjadi seorang remaja yang dikenal aktif dan memiliki jaringan yang luas. Pada masa ini, A. Latief Muchtar mulai berinteraksi dengan Persis secara organisasi dengan masuk menjadi anggota dari Pemuda Persis (Wildan, 1997: 142).
Pilihan A. Latief Muchtar untuk aktif semasa remaja dalam organisasi Rijalul Ghad dan Pemuda Persis telah mempengaruhi pemikiran A. Latief Muchtar. Organisasi adalah tempat dimana berkumpulnya orang yang memiliki karakter beragam. kepemimpinan A. Latief Muchtar dalam kedua organisasi tersebut telah membentuk pemikirannya yang tidak hanya membenarkan pendapatnya saja, melainkan mengajak semua orang untuk membicarakan kebenaran.

Selepas menamatkan pendidikan tingkat menengah pertama dan atas di Muallimin Persis dan SMA Belitung, kemudian beliau meneruskan studinya ke Sekolah Tinggi Hukum dan Pengetahuan Masyarakat di Jakarta. Ketika beliau menimba ilmu di sana, A. Latief Muchtar merasa tidak ada aspek intelektual yang bertambah secara signifikan sehingga beliau hanya bertahan belajar disana selama dua tahun (Wildan, 1997 : 142, Rahman, 1999 : 42).

Pada muktamar ke -11 Pemuda Persis pada tanggal 17 sampai 20 September 1953, bertepatan dengan muktamar V Persis, A. Latief Muchtar terpilih sebagai Ketua Umum Pimpinan Pusat Pemuda Persis masa jihad 1953-1956. Namun karena kesibukannya hendak berangkat ke luar negeri, posisi beliau untuk selanjutnya digantikan oleh Yahya Wardi yang pada saat itu menjabat sebagai Ketua I Pimpinan Pusat Pemuda Persis (Risalah No. 9 Th. XXXV Nopember 1997).

Cita-cita A. Latief Muchtar ternyata melampaui batas ruang benua. A. Latief Muchtar hendak meneruskan belajarnya ke luar negeri, tepatnya adalah kota Kairo Mesir. Keinginan ini untuk kemudian bisa diraihnya berkat kemampuan bahasa Arab dan Inggris A. Latief Muchtar yang baik. Akhirnya keinginan tersebut berhasil diraih olehnya yang berangkat ke Mesir pada bulan Oktober tahun 1957. Ketika kuliah di Mesir beliau mengambil program strata 1 di Universitas Darul Ulum Kairo jurusan Syariah. Beliau berhasil menamatkan S1 pada tahun 1962. Kemudian ia melanjutkan studinya ke Ma'had Dirasah Islamiyyah (Institut of Islamic Studies) selama dua tahun sehingga selesai pada tahun 1964. Teman kuliahnya ketika di Mesir antara lain K.H. Ahmad Azhar Basyir, salah mantan ketua umum PP. Muhammadiyyah (Rahman, 1999 : 43).

HISTORIA: Jurnal Pendidik dan Peneliti Sejarah, p-issn:2620-4789 | e-issn:2615-7993 
Sebagai seorang mahasiswa yang jauh dari tanah air, A. Latief Muchtar berusaha untuk hidup di Mesir dengan keringatnya sendiri melalui bekerja di Kantor Kedutaan Besar Republik Indonesia (KBRI). Pekerjaan ini ternyata untuk selanjutnya memberikan nilai positif yang banyak karena dengan pekerjaan ini A. Latief Muchtar bisa bertemu dengan para mahasiswa Indonesia yang juga sedang kuliah di Mesir. Forum pertemuan di KBRI itulah membawa A. Latief Muchtar bertemu dengan Ibrahim Hussein yang bersama-sama dengannya mendirikan Himpunan Pelajar Pemuda Indonesia (HIPPI). Ibrahim Hussein sebagai Ketua dan A. Latief Muchtar terpilih untuk mendampingi Ibrahim Hussein sebagai Sekretaris (Wildan, 1997: 142-143).

Selama menjalani perkuliahan di Mesir tersebut A. Latief Muchtar menjadi seorang mahasiswa yang gemar melakukan olahraga. Beberapa olah raga pernah A. Latief Muchtar lakukan dari mulai tenis meja, badminton, sepak bola sampai olah raga billiar pun beliau ikuti, namun dua jenis olah raga yang sangat sering A. Latif Muchtar ikuti adalah tenis meja dan sepak bola. Kebiasaan ini terbawa sampai tatkala beliau menjalani kehidupan di Indonesia. Klab olahraga sepakbola lokal favorit A. Latief Muchtar adalah Persib, sebuah klab tua yang berdiri di Bandung (Muhammad, 1998 : xL). Kesukaannya pada sepak bola ini diikuti oleh anaknya. Ketika berlangsung partai final Liga Indonesia pertama antara Persib dan Petrokimia Putra di stadion Senayan Jakarta, beliau menyempatkan diri untuk menontonnya, padahal pada saat itu A. Latief Muchtar baru saja pulang dari Bima bersama ustadz Siddiq Aminullah. Awalnya dari Bima beliau akan langsung pulang dan mendarat di bandara Hussein Sastranegara Bandung, namun karena terdapat kesalahan tekhnis, maka penerbangan harus transit terlebih dahulu di Bandara Soekarno Hatta Jakarta. Bagi A. Latief Muchtar, itu merupakan kesempatan emas karena di Jakarta akan berlangsung partai final Liga Indonesia. Sesampainya A. Latief Muchtar di Bandara, beliau langsung berkunjung ke Stadion Senayan dalam keadaan masih memakai batik dan kopernya dititip di ke Ustadz Siddik Aminullah untuk dibawa ke Bandung memakai kereta. Setelah tiba di stadion dalam keadaan masih memakai pakaian batik, beliau meminta salah satu anaknya yang juga nonton pada saat itu untuk membelikan kaos Persib. Tidak hanya itu, hobi nonton bola yang A. Latief Muchtar miliki, menurut putranya sering terjadi di rumah beliau. Hanya sekedar untuk menonton sepak bola liga Italia yang disiarkan RCTI, beliau rela tidak tidur tengah malam, bahkan beliau selalu menontonnya sampai subuh hari.

Sifat A. Latief Muchtar yang sering melindungi terhadap sesamanya, termasuk adiknya masih sering dilakukan termasuk saat adiknya, Yusuf Amir Feisal singgah ke Mesir dari perjalanan pulang ke Indonesia dari studinya di Amerika. Tatkala mereka sedang melakukan olahraga tenis lapangan berdua, datang seorang negro Arab yang mengganggu, tetapi dengan memakai bahasa Sunda, A. Latief Muchtar berucap "keun urang akang jebrod" (biar kakak pukul) untuk memberikan rasa aman terhadap adiknya yang sesungguhnya tidak perlu dilindungi lagi (Feisal : 03/06/2005).

A. Latief Muchtar dewasa sudah sampai pada titik kedewasaannya. Hal tersebut ditandai dengan kehendaknya untuk mempersunting gadis Sunda bernama Aisyah Wargadinata, seorang mahasiswi Fakultas Hukum Universitas Padjajaran (Unpad) yang ia kenal dari sejak lama. Aisyah Wargadinata dilahirkan pada tanggal 21 September 1936 di kota Tasikmalaya, terpaut lima tahun dari A. Latief Muchtar. Proses pernikahan A. Latief Muchtar dilakukan dengan nikah wali, yakni sebuah proses pernikahan yang pihak calon pengantin laki-lakinya diwakilkan kepada orang lain.

Pada kesempatan ini, wali A. Latief Muchtar diwakilkan kepada ustadz Yahya Wardi, salah satu pimpinan Pemuda Persis. Prosesi nikah wali ini sama sekali tidak dikenal oleh masyarakat Indonesia, apalagi para pemuda yang minim pengetahuan agama. Hal ini merupakan sebuah terobosan baru yang dikembangkan oleh salah seorang pemuda Indonesia. Saat pernikahannya dengan Aisyah Wargadinata berlangsung, istrinya tersebut masih tercatat sebagai mahasiswa tingkat dua di Universitas Padjadajaran (Unpad) Bandung, namun karena berbagai alasan, akhirnya pada tahun 1962, Aisyah Wargadinata menyusul suaminya ke Mesir untuk menimba ilmu di Kulliyatul Banaat (Fakultas khusus wanita) Universitas Al-Azhar Kairo dengan mengambil Jurusan Syariah. 
Pernikahan A. Latief Muchtar dengan Aisyah Wargadinata kemudian dikaruniai tiga orang putra. Pertama, Irfan Setiana Latief Muchtar yang sekarang menjadi pegawai PT Pos Indonesia. Kedua Iman Setiawan Latief yang sekarang menjadi anggota Dewan Perwakilan Rakyat Daerah (DPRD) Kota Bandung dari Partai Bulan Bintang (PBB), dan ketiga Ihsan Setiadi Latief yang sekarang menjadi Ketua Sekolah Tingggi Keguruan dan Ilmu Pendidikan (STKIP) Persis dan Sekretaris Pimpinan Wilayah (PW) Pemuda Persis Jawa Barat (Latief: 30/05/2005).

Dua dari anak A. Latief Muchtar yang paling tua dilahirkan tatkala A. Latief Muchtar masih menimba ilmu di Mesir, sementara anak bungsunya dilahirkan di Indonesia. Dalam perjalanan keluarga, memiliki tiga orang anak bagi A. Latief Muchtar dan Aisyah Wargadinata bukanlah sesuatu yang direncanakan oleh mereka, tetapi memiliki alasan tersendiri. A. Latief Muchtar sesungguhnya menghendaki memiliki putra lebih dari tiga atau sebanyak-banyaknya, namun karena kondisi istrinya yang sudah menjalani operasi sesar sebanyak dua kali, maka dokter memberikan rekomendasi untuk tidak memiliki putra lagi karena terlalu riskan. Apabila hamil, maka kemungkinan kematian baik untuk ibu maupun anaknya sangat besar (Latief : 30/05/2005). Sikap ini sesungguhnya memiliki relevansi dengan pemahaman A. Latief Muchtar yang lebih moderat dengan pertimbanganpertimbangan hukum Islam. Keluarga Berencana (KB) sebagai program pemerintah kadang dianggap haram bagi sebagian kalangan anggota Persis, tetapi keluarga A. Latief Muchtar menjalankan KB dengan pertimbangan kesehatan istrinya yang sangat rentan. Dalam persoalan seperti ini, posisi A. Latief Muchtar sebagai seorang ahli bidang agama sangat dibutuhkan untuk memberikan kejelasan terhadap sebuah hukum.

Irfan Setiana Latief Muchtar sebagai putra sulung pada awalnya memiliki keinginan untuk menjadi aktifis Persis, tetapi hal tersebut dilarang A. Latief Muchtar, namun dalam perkembangan selanjutnya, justru kedua putra lainnya yang berkecimpung di Persis. Pelarangan A. Latief Muchtar terhadap anak sulungnya terkesan sangat bertolak belakang dengan karakter umum beliau yang cenderung demokratis dan tidak mendikte.
Setelah menyelesaikan kuliah di Mesir, A. Latief Muchtar pulang ke Indonesia pada tahun 1970. Banyak hal dilakukan oleh A. Latief Muchtar sepulangnya dari Mesir. Kepulangan A. Latief Muchtar ke Indonesia disambut oleh Ustadz Abdurrahman yang pada saat itu menjabat sebagai Ketua Umum PP. Persis dengan mengadakan tasyakuran atau seremoni sebagai rasa syukur atas keberhasilan A. Latief Muchtar menyelesaikan kuliahnya dengan baik (Sastranegara : 04/04/2005).

Perjalanan dakwah A. Latief Muchtar di Persis setelah kepulangan beliau dari Mesir diawali ketika ia diberi amanah untuk menggantikan posisi Ustadz Yunus Anis yang meninggal dunia pada tanggal 23 Mei 1972 sebagai Sekretaris Umum PP. Persis. Melalui musyawarah lengkap PP. Persis tanggal 2 April 1973 diputuskan bahwa jabatan Sekretaris Umum periode 1967-1981 di bawah kepemimpinan E. Abdurrahman dilimpahkan kepada A. Latief Muchtar. Langkah yang telah mengantarkan A. Latief Muchtar menjadi salah satu pimpinan Persis adalah ketika ia terpilih sebagai Ketua I PP. Persis pada Muakhot tanggal 16-18 Januari 1981 di Bandung untuk mendampingi K.H.E. Abdurrahman sebagai Ketua Umum. Dua tahun kemudian, pada hari kamis, tanggal 21 April 1983, ustadz Abdurrahman meninggal dunia, dan posisi Ketua Umum digantikan oleh A. Latief Muchtar sebagai pejabat Ketua Umum hasil musyawarah lengkap Pimpinan Pusat Persis tanggal 1 Mei 1983 yang keputusannya melimpahkan jabatan Ketua Umum kepada Ketua I. Untuk selanjutnya melalui muktamar ke 10 di Pondok Pesantren Persis Tarogong Garut Jawa Barat, A. Latief Muchtar terpilih sebagai Ketua Umum PP. Persis. Ketika berlangsung Muktamar ke 11 di Asrama Haji Pondok Gede Jakarta, A. Latief Muchtar kembali terpilih sebagai seorang Ketua Umum PP. Persia masa kepengurusan 1995 sampai 2000 (Wildan, 1997 : 145, Arsip PP. Persis, Qanun Asasi dan Qanun Dakhili Persis).

Persis di bawah kepemimpinan A. Latief Muchtar mencoba mendirikan Perguruan Tinggi pertama dalam kalangan Persis. Pada tahun 1988 berdirilah Pondok Pesantren Tinggi, kemudian Perguruan Tinggi tersebut bernama Sekolah Tinggi Ilmu Ushuluddin (STIU) Persis yang untuk kemudian beliau menjadi ketuanya dari tahun 1990 sampai 1993, tetapi dalam perjalanannya Perguruan HISTORIA: Jurnal Pendidik dan Peneliti Sejarah, p-issn:2620-4789 | e-issn:2615-7993 
Tinggi tersebut berubah nama menjadi Sekolah Tinggi Agama Islam (STAI) Persis. Di STAI Persis yang memiliki dua jurusan, yakni jurusan Dakwah dan Tafsir Hadits, A. Latief Muchtar menjadi dekannya. Kebahagiannya terpancar ketika buah dari cita-cita dan pemikirannya untuk mendirikan Perguruan Tinggi berhasil meluluskan para sarjana agama Islam dari STAIPI pada saat wisuda perdana tanggal 28 Juli 1997. A. Latief Muchtar berkata lirih "Akhirnya berhasil juga, dan tiba saatnya wisuda sarjana mahasiswa STAIPI” (Wildan, 1997 : 149).

Karir akademis A. Latief Muchtar pertama kali beliau dapatkan pada tahun 1971 sampai 1974, beliau menjadi salah satu dosen Agama Islam di Institut ternama di Indonesia, Institut Teknologi Bandung (ITB), selain itu juga dari tahun 1974 sampai 1994 beliau menjadi dosen Ilmu Tafsir dan Bahasa Arab di Institut Agama Islam Negeri Sunan Gunung Djati (IAIN SGD) Bandung. Karir akademis di kampus tersebut, mengantarkan beliau pernah menjadi Pembantu Rektor I IAIN Sunan Gunung Djati Bandung untuk dua periode. Di kampus lain pada tahun 1970 sampai 1974 beliau sempat manjadi dosen sekaligus Dekan Fakultas Ushuludin Universitas Islam Bandung (Unisba) dan Mudir Sekolah Tinggi Agama Islam Persatuan Islam (STAIPI) (Risalah No 9 Th. XXXV Nopember 1997). Disamping itu beliau juga pernah mengajar di Institut Keguruan dan Ilmu Pendidikan (IKIP) Bandung pada jurusan Bahasa Arab.

Ketika menjadi dosen tetap dan Pembantu Rektor 1 IAIN Sunan Gunung Djati Bandung, A. Latief Muchtar sudah berusia sekitar 40 tahun golongan III/a dengan gaji yang tidak terlalu besar. Namun baginya mengajar bukan hanya sekedar mencari materi tetapi mengajar merupakan sebuah aktifitas yang tidak bisa dipisahkan dari berdakwah dan kehidupan. Menurut Afif Muhammad yang merupakan teman di kampusnya, selama menjadi dosen A. Latief Muchtar sangat jarang menampakkan wajah mendung sebab bagi A. Latief Muchtar mengajar dan berdakwah memberikan kenikmatan tersendiri. A. Latief Muchtar sering berujar banyak belajar dari para mahasiswanya tatkala beliau keluar dari kelas untuk kemudian berbincang-bincang dengan teman sesama dosen (Muhammad, 1998 : XLiii).
Sebagai seorang akademisi, A. Latief Muchtar belum puas dengan hanya kuliah sampai program S1 dari Mesir, A. Latief Muchtar kemudian melanjutkan studinya ke jenjang program S2 pada program pasca sarjana IAIN Syarif Hidayatullah Jakarta. Studinya tersebut, A. Latief Muchtar selesaikan pada tahun 1984. Kemudian ia melanjutkan ke jenjang S3 di kampus yang sama, namun karena kesibukannya, beliau tidak sempat menyelesaikannya (Rahman, 1999 : 43).

A. Latief Muchtar merupakan asshaabiqunal awwalun (golongan pertama) pada program pasca sarjana IAIN Syarif Hidayatullah Jakarta yang baru dibuka pada tahun 1982. Di sana, A. Latief Muchtar banyak berinteraksi dengan dosen-dosen terkemuka, diantaranya adalah Deliar Noer, $\mathrm{H}$. M. Rasjidi, Ahmad Baiquni, Taufiq Abdullah, Sutan Takdir Alisyahbana, dan Harun Nasution. Mahasiswa Pasca Sarjana IAIN Syarif Hiyatullah Jakarta merupakan tokoh dan kiai yang terkemuka, diantaranya Buya Mansur Malik, seorang ketua Muhammadiyah wilayah Sulawesi Selatan (Muhammad, 1998 : XLi).

Kuliah di pasca sarjana IAIN Syarif Hidayatullah Jakarta benar-benar sangat berat. Seluruh mata kuliah ditempuh dengan sistem seminar. Masingmasing mahasiswa harus menulis makalah untuk setiap mata kuliah. Belum lagi tugas-tugas berupa chapter report, book report, resensi dan penerjemahan berbagai teks. Begitu beratnya perkuliahan tersebut, sampai-sampai berkembang sebuah tahkayul di kalangan mahasiswa yang menyatakan bahwa pada setiap angkatan selalu terdapat korban karena di setiap angkatan selalu ada saja yang meninggal dunia sebelum merampungkan kuliahnya (Muhammad, 1998 : XLii).

Ketika kuliah di program Pasca Sarjana IAIN Syarif Hidayatullah Jakarta, A. Latief Muchtar menjadi mahasiswa yang tinggal di asrama. Kondisi di asrama dan tanah di sekitarnya belum berpagar, sehingga ayam dan kambing sering berkeliaran di sekitar asrama tampat A. Latief Muchtar tinggal. Pakaian yang dijemur para mahasiswa sering mereka bawa. Akibat kambing-kambing tersebut, sekali waktu, salah seorang kiai yang juga mahasiswa pasca sarjana menangkap seekor kambing yang berkeliaran tersebut, bukan untuk disembelih atau 
disate, tetapi untuk dipakaikan baju dan dilepas kembali. Tentu saja hal tersebut merupakan tontonan yang menarik di tengah beratnya kuliah (Muhammad, 1998 : XLii).

Selama di asrama, beliau diamanahi untuk menjadi Lurah Asrama. Setiap subuh, beliau menggedor pintu kamar, lalu adzan dan sekaligus menjadi imamnya. Ketika para penghuni asrama lainnya mencari sarapan di luar asrama, beliau justru ngliwet (masak beras) sendiri di dapur, padahal saat itu beliau sudah menjadi kiai besar yang dihormati ummat (Muhammad, 1998 : XLii).

Perjalanan A. Latief Muchtar di program pasca sarjana IAIN Syarif Hidayatullah Jakarta memperlihatkan keinginan yang kuat untuk lebih memperluas wawasan keagamaan. A. Latief Muchtar seolah tidak puas dengan ilmu yang telah beliau dapatkan dari Timur Tengah. Menurut pandangan penulis, A. Latief Muchtar memahami konstelasi pemikiran yang berkembang di IAIN, tetapi hal tersebut tidak membuat A. Latief Muchtar menjadi alergi dengan pemikiran-pemikiran tersebut. Hal inilah yang juga mempengaruhi paradigma A. Latief Muchtar dalam memandang perbedaan.

Selain kuliah pada Pasca Sarjana IAIN Syarif Hidayatullah, sebagai seorang tokoh nasional, A. Latief Muchtarjuga aktifdi beberapa organisasiselain Persis, antara lain Majelis Ulama Indonesia (MUI) dan Ikatan Cendekiawan Muslim Indonesia (ICMI) pusat sebagai anggota Dewan Penasihat. Menurut A. Latief Muchtar keberadaan ICMI di bawah figur sentral Habibie akan mampu memberikan nilai-nilai Islamisasi di dalam birokrasi, parlemen dan kabinet. Di bawah kepemimpinan A. Latief Muchtar, Persis dibawa secara organisasi untuk aktif mendukung program-program ICMI (Rahman, 1999 : 102). Selain itu aktifitas A. Latief Muchtar juga menjadi anggota presidium Forum Ukhuwah Islamiyah dan juga Dewan Panasihat Pusat Inkubasi Bisnis Usaha Kecil (Risalah No 9 Th. XXXV Nopember 1997).

Keterlibatan A. Latief Muchtar dalam ICMI merupakan perkembangan menarik dari beliau. Masuknya beliau ke dalam ICMI selain karena kesempatan yang ada, juga semakin memperjelas keinginan A. Latief Muchtar untuk Persis lebih mampu berperan dalam pemerintahan seperti tokoh-tokoh Persis terdahulu yang mampu berkomunikasi baik dengan pihak presiden.
Hal yang paling kontroversial dari tokoh A. Latief Muchtar selama memimpin Persis adalah dengan bergabungnya beliau dengan salah satu partai politik masa Orde Baru, Partai Persatuan Pembangunan (PPP) pada akhir masa hidupnya. Pilihan ini berlangsung di tengah-tengah kalangan anggota Persis yang pada saat itu masih merasa tabu dengan politik praktis yang sudah sangat lama ditinggalkan Persis. Menurut Latief (30/05/2005) alasan A. Latief Muchtar memilih untuk aktif di PPP merupakan bagian dari upaya A. Latief Muchtar untuk memperlebar pengaruh dakwah. Persis yang selama kepemimpinan E. Abdurrahman berkonsentrasi pada bidang dakwah dan pendidikan dicoba untuk diperbaharui dengan masuk dunia politik, sekalipun masuknya beliau ke PPP atas dasar pribadi. Pilihan untuk menyatakan diri masuk ke PPP secara pribadi tampaknya ditempuh setelah melihat anggota Persis yang masih sangat tabu untuk masuk dunia politik praktis. Setelah A. Latief Muchtar tetap menyatakan bergabung dengan PPP, perkembangan selanjutnya ternyata keterlibatan A. Latief Muchtar dalam PPP telah mampu merubah pandangan sebagian anggota Persis menjadi sangat terbuka dengan politik praktis, bahkan sebagian dari mereka secara terang-terangan memilih PPP sebagai pilihan politiknya.

Bergabungnya A. Latief Muctar kepada PPP banyak menuai kritik, baik dari keluarga maupun kalangan Persis. Sebelum kepemimpinan beliau, Persis di bawah Ustadz E. Abdurrahman seolaholah mengisolir diri dari percaturan politik praktis di Indonesia sehingga kebijakan tersebut banyak mengagetkan anggota Persis. Pada saat A. Latief Muchtar mendiskusikan niat masuknya beliau ke PPP, salah satu anaknya, Ihsan Setiadi Latief menyatakan secara langsung ketidak setujuannya. Sementara dalam tubuh Persis, penolakan terbesar muncul dari Pemuda Persis yang dipimpin Atif Latiful Hayat. Kebijakan A. Latief Muchtar masuk PPP sampai mengundang beberapa kalangan dalam Persis mempertanyakan keberadaan Persis dengan menyitir sebuah ayat Al-Quran yang berbunyi "Fa aina tadzhabuun?" (kemanakah engkau akan pergi ?) (Departemen Agama, 1994 : 1029).

Bergabungnya A. Latief Muchtar terhadap partai politik sesungguhnya juga melalui perjalanan yang tidak sebentar. Sebelum A. Latief Muchtar HISTORIA: Jurnal Pendidik dan Peneliti Sejarah, p-issn:2620-4789 | e-issn:2615-7993 
ditawari masuk PPP, corong penguasa Orde Baru, Golongan Karya (Golkar) juga sempat menawari beliau untuk menjadi salah satu kadernya, namun A. Latief Muchtar menganggap bahwa PPP merupakan representasi kaum muslimin yang paling proporsional. Hal ini memperlihatkan bahwa keterlibatan beliau dalam partai politik bukan hanya berlandaskan kepada keinginan untuk merasakan kekuasaan saja, melainkan atas dasar perjuangan Islam.

Selama Perjalanan keikut sertaannya aktif di PPP, A. Latief Muchtar lebih banyak meminta pendapat dari seniornya dalam politik yakni Anwar Haryono, salah satu tokoh pelanjut perjuangan M. Natsir yang pada saat itu menjabat sebagai ketua Dewan Dakwah Islam Indonesia (DDII) dan K.H. Rusyad Nurdin, tokoh Persis yang dikeluarkan karena keaktifannya di Parmusi Jawa Barat. Kedua tokoh ini seolah menjadi guru dan tempat berdiskusi. Ihsan Setiadi Latief, salah satu anak A. Latief Muchtar menguatkan hal ini dengan menyatakan bahwa keterlibatan A. Latief Muchtar banyak dikuatkan oleh masukan-masukan dari kedua tokoh ini (Latief : 30/05/2005). Pilihan A. Latief Muchtar untuk banyak berdiskusi dengan pihak luar Persis dalam persoalan politik memperlihatkan bahwa A. Latief Muchtar menganggap tokoh Persis pada saat itu tidak memiliki wawasan politik yang cukup untuk diajak berbicara politik kontemporer karena begitu lamanya mereka meninggalkan politik.

Melalui Pemilu tahun 1997, akhirnya A. Latief Muchtar terpilih sebagai anggota DPR/ MPR RI dari daerah pemilihan Jawa Barat. Sekalipun telah terpilih menjadi salah satu anggota legislatif, namun suaranya tidak pernah terdengar menyuarakan aspirasi masyarakat karena A. Latief Muchtar wafat sebelum beliau disumpah. Bagi beberapa kalangan dalam tubuh Persis, hal ini merupakan sesuatu yang terbaik untuk A. Latief Muchtar karena PPP merupakan sebuah partai sekuler (Rahman, 1999 : 195). Sebagian anggota Persis menganggap bahwa wafatnya A. Latief Muchtar sebagai sebuah bentuk penyelamatan Allah terhadap diri beliau karena pada saat pelantikan anggota DPR MPR RI terdapat beberapa prosesi yang menurut Persis merupakan bentuk syirik (menyekutukan Allah) terhadap aspek tauhidullah, salah satunya adalah penghormatan terhadap bendera dan janji atas dasar Pancasila.
Sebagai tokoh nasional, A. Latief Muchtar sangat akrab dengan $M$. Natsir yang berperan sebagai gurunya. Hal inilah yang akan mengantarkan beliau pada pergaulan internasional. Beberapa kali A. Latief Muchtar mewakili M. Natsir dalam forum-forum internasional. Melalui jalinan internasionalnya yang banyak dan sering, A. Latief Muchtar berkalikali melakukan kunjungan ke negara-negara Timur Tengah dalam proses pencarian dana untuk pembangunan sarana dan prasarana fisik ummat Islam Indonesia, khususnya anggota Persis. Besarnya dana yang didapatkan dari lawatannya tersebut melebihi kumpulan dana yang dimiliki oleh Persis saat ini. Kiprahnya di dunia intenasional diwadahi dalam forum Organisai Konferensi Islam (OKI) dan juga Majlis Ta’sisi Rabithah 'Alam Islami (Moslem World League). Dalam muktamar internasional, A. Latief Muchtar sering mengikuti diskusi-diskusi muslim dunia di Pakistan, Maroko, Mesir, Riyadl, Aljazair, Libya, Malaysia dan Srilangka (Risalah No. 9 Th. XXXV Nopember 1997 : 20).

Perjalanan hidup A. Latief Muchtar yang panjang telah menjadikan sosok A. Latief Muchtar memiliki karakter kuat dalam dakwah. Salah satu tokoh yang memberikan penilaian tersebut adalah Tarmizi Taher, seorang mantan mentri agama pada masa Orde Baru. Dalam pandangan Taher (1998 : xxvi) Persis dan A. Latief Muchtar merupakan "organisasi Islam dan pemimpin ummat yang tidak ragu-ragu menyampaikan koreksi”.

Sebelum seluruh idealismenya terwujud, A. Latief Muchtar terkena serangan jantung di Hotel tempat A. Latief Muchtar menginap untuk keperluan pelantikan anggota DPR/ MPR RI. A. Latief Muchtar kemudian dilarikan ke Rumah Sakit Pusat Angkatan Darat (RSPAD) Gatot Subroto Jakarta namun akhirnya beliau menghembuskan nafas yang terakhir pada hari Senin, 13 Oktober 1997 bertepatan dengan 11 Jumadits Tsani $1418 \mathrm{H}$ pukul 02.00 dini hari. Jenazah diberangkatkan dari RSPAD Gatot Subroto Jakarta menuju Bandung di jalan Lengkong Besar Gang Ancol Utara I No. 44/ 36 D. Sesuai dengan pemahaman fiqhiyyah Persis yang harus menyegerakan pemakaman seseorang yang meninggal, Jenazah disemayamkan hanya sampai pukul 08.00 untuk kemudian dishalatkan di mesjid Persis, Jalan Pajagalan No. 14 Bandung. 
Ribuan pelayat melakukan shalat jenazah dan mengantarkannya ke pekuburan Cijeungjing Buah Batu Bandung pada pukul 10.00 WIB (Wildan, 1997 : 159). Menurut putranya, identitas seorang A. Latief Muchtar terlihat tatkala beliau meninggal. Hampir semua lapisan masyarakat dari mulai pejabat, intelektual, tokoh agama bahkan rakyat biasa ikut menghadiri pemakaman (Latief : 30/05/2005).

\section{Pemikiran A. Latief Muchtar Terhadap Perubahan Sikap Politik Persatuan Islam}

A. Latief Muchtar mencoba menerapkan beberapa tradisi dan pemikiran baru dalam kultur dan kebiasaan Persis. Beberapa dari kebijakan tersebut telah berangsur-angsur mengubah pandangan anggota Persis dan juga mengubah pandangan beberapa kalangan terhadap keberadaan Persis di Masyarakat.

Pada masa kepemimpinan K.H.E. Abdurrahman, Persis dibawa untuk hanya membenahi perkembangan internal saja. Imbas dari kebijakan tersebut mengantarkan anggota Persis menjadi sangat tabu untuk berpolitik praktis sampai akhirnya pada tahun 1983, K.H. E. Abdurrahman wafat, Persis masih dalam kondisi tidak terpublikasikan. Persis tidak hendak muncul ke permukaan sebagai salah satu organisasi yang memiliki suara tersendiri. Kepemimpinan A. Latief Muchtar yang menggantikan K.H. E. Abdurrahman pada tahun 1983 mencoba menawarkan hal yang baru bagi perjuangan Persis. Kebijakan-kebijakan Orde Baru yang telah banyak merugikan ummat Islam coba disikapi lebih arif oleh kepemimpinan A. Latief Muchtar. Keinginannya untuk meningkatkan kualitas anggota yang dipimpinnya diwujudkan melalui pendekatan persuasif. Melalui kepemimpinannya, Persis tidak lagi mengisolir diri dari berbagai persoalan ummat (Wildan, 1997 : 147).

Kiprah dalam bidang jam'iyyah (organisasi), A. Latief Muchtar bertekad menjadikan Persis sebagai sebuah organisasi yang mandiri, tanpa mengisolir diri, Persis tidak mengikatkan diri pada kekuatan lain meskipun tetap membuka diri. A. Latief Muchtar mencoba menampilkan Persis sebagai gambaran mini dari bunyaanul mukmin yang saling menopang satu sama lain. A. Latief Muchtar membenahi struktur organisasi dengan mencoba melibatkan organisasi dalam cakupan yang lebih luas. Pandangan eksklusif terhadap Persis yang muncul dalam masyarakat mampu diubah menjadi pandangan yang lebih cair sehingga akhirnya masyarakat mengakui Persis sebagai salah satu organisasi yang tidak ditakuti.

Kiprah dalam bidang dakwah, A. Latief Muchtar memberikan warna baru terhadap dinamika peta dakwah di Indonesia. Persis tidak tampil dengan gebrakan-gebrakan, tetapi melalui pendekatan persuasif edukatif. Menurut Wildan (1997: 147) Persis tidak lagi garang dan menantang. Kini Persis tampil untuk mencari jelas bukan mencari puas. Cakupan dakwah yang dicanangkan A. Latief Muchtar tidak hanya terbatas pada rutinitas dakwah di kalangan anggota dan simpatisannya saja. Karena itu A. Latief Muchtar bercita-cita mengembangkan objek dakwahnya ke masyarakat kampus dengan mendukung penuh pembentukan Himpunan Mahasiswa dan Himpunan Mahasiswi Persis. Hal ini sesuai dengan pemikiran pendekatan dakwah A. Latief Muchtar yang mengedepankan dakwah bil hikmah wal mauidhatil hasanah (dakwah dengan kebijaksanaan dan nasihat yang baik), serta mengedepankan dialog agar tidak menjadi konflik di masyarakat. Pemikiran ini tertuang dalam nasihat terakhir beliau dalam wawancara dengan majalah Risalah setelah beliau terpilih menjadi ketua umum Persis kembali pada tahun 1995.

Kiprah dalam bidang ekonomi, pemikiran A. Latief Muchtar menjurus ke arah pemberdayaan ummat Islam dengan tujuan meningkatkan kesejahteraan ummat sekaligus menghindari praktek bisnis dan perbankan yang masih menggunakan sistem bunga konvensional. A. Latief Muchtar kemudian membentuk Bank Pengkreditan Rakyat (BPR) sebagai bentuk bank Islam tanpa bunga. A. Latief Muchtar duduk sebagai komisaris BPR Amanah Robbaniyah. Hal ini sesuai dengan pemikiran A. Latief Muchtar dalam bidang ekonomi yang ingin memiliki perekonomian ummat yang terbebas dari riba. Berdirinya BPR juga merupakan sebuah pembuktian awal bahwa Islam memiliki peranan dalam bidang ekonomi.

Kiprah dalam bidang pendidikan A. Latief Muchtar menekankan pentingnya peningkatan kualitas dan kuantitas Pesantren Persis yang

HISTORIA: Jurnal Pendidik dan Peneliti Sejarah, p-issn:2620-4789 | e-issn:2615-7993 
tersebar di seluruh Indonesia. Cita-cita dalam bidang pendidikan terkejawantahkan dengan berdirinya Perguruan Tinggi milik Persis (Wildan, 1997: 150). Pada kepemimpinan A. Latief Muchtar pesantren berhasil menjadi lembaga pendidikan yang tidak lagi termarjinalkan. Pemikiran A. Latief Muchtar tentang eksistensi pesantren yang harus mampu menyesuaikan diri dengan tantangan zaman mampu terealisasi dengan perubahan yang terjadi dalam sistem pesantren Persis sehingga akhirnya lulusan pesantren Persis bisa diterima di Perguruan Tinggi Negeri Indonesia. Bahkan berkat peranannya, banyak dari lulusan Pesantren Persis yang berhasil melanjutkan belajarnya ke Timur Tengah. Perkembangan yang terjadi dalam pendidikan Persis merupakan pengaruh yang ditimbulkan dari pemikiran dan kepemimpinan A. Latief Muchtar yang bukan hanya mementingkan pendidikan konvensional pesantren melainkan juga harus menyesuaikan diri dengan perkembangan zaman.

Ketika Orde Baru mengharuskan seluruh organisasi sosial politik mencantumkan Pancasila sebagai asasnya, Persis menerima kenyataan tersebut dengan menerima Pancasila sebagai asas baru Persis dan mencantumkannya dalam Qanun Asasi secara resmi pada tahun 1987. A. Latief Muchtar dalam momen ini berhasil memberikan pemecahan tanpa terjadi konflik yang berarti dalam tubuh Persis. Beliau tidak menggunakan momen besar seperti muktamar atau rapat luar biasa seperti organisasi lainnya yang berakibat kepada munculnya perpecahan, tetapi A. Latief Muchtar mencoba untuk mengkomunikasikan hal ini dengan anggota Persis di daerah-daerah (Aminullah: 05/06/2005). Sebagai akademisi di bidang Syariah, A. Latief Muchtar mengetahui tentang tata cara pengambilan sebuah keputusan hukum dalam Islam. Pada dasarnya Persis tidak menerima pemikiran sekuler dalam bentuk apapun, termasuk dalam politik, namun dalam persoalan Pancasila, Persis terlihat lebih akomodatif dengan kebijakan pemerintah Orde Baru, bahkan terjadang, beliau mencari-cari alasan untuk bisa menerima Pancasila sebagai asas organisasi. Dalam pandangan penulis hal ini memiliki relevansi dengan pemikiran A. Latief Muchtar sebagai seorang pakar syariah yang memiliki landasan berfikir syariah Islam. Akhirnya alasan penerimaan Persis terhadap Pancasila juga berlandaskan kepada pemikiran syar'i yaitu menggunakan kaidah-kaidah Ushul Fiqh yang berlaku. Sejak dari penerimaan Persis terhadap Pancasila pada tahun 1987 sampai berakhirnya kepemimpinan A. LatiefMuchtar, Persis sesungguhnya tidak secara betul-betul menerima Pancasila sebagai asas organisasi sekalipun banyak alasan yang dikemukakan untuk melegalkan pilihan Persis tersebut berdasarkan hukum syar'i. Persis tetap memiliki pandangan bahwa Islam sebagai sebuah asas yang sesungguhnya harus dijalankan.

Pendekatan kepemimpinan A. Latief Muchtar yang toleran merupakan bagian dari keterbukaan politik baru yang dimiliki oleh Persis di bawah kepemimpinannya. Keterbukaan ini juga ditandai dengan kedekatan Persis dengan pemerintah. Setelah menerima Pancasila sebagai asas, Persis kemudian merupakan organisasi sosial kemasyarakatan yang pertama kali menyatakan dukungannya teradap Dr. Ing. BJ Habibie dalam pencanangan hari teknologi nasional (Nurmalasari, 1999: 41). Pendekatan ini adalah sebuah upaya Persis untuk tidak menjaga jarak dengan pemerintahan. Keterhubungan visi Habibi dan A. Latief Muchtar tentang pendidikan yang hendak menyatukan Imtak dan Iptek menjadikan Persis sangat mendukung program pemerintah dalam bidang ini. A. Latief Muchtar menyadari bahwa Persis sangat ketinggalan dalam bidang teknologi sehingga ketika pemerintah memiliki kesadaran untuk meningkatkan kemampuan teknologi, A. Latief Muchtar bersama Persis berupaya untuk tidak kehilangan momentum dalam memajukan Persis melalui teknologi.

Pada tahun 1990 dalam muktamar Persis yang ke 10 di Garut Jawa Barat, Persis menghadirkan perwakilan dari pemerintah yang diwakili oleh Mentri Dalam Negeri dan Mentri Agama. Harian Kompas pada saat berlangsungnya Muktamar tersebut sempat memberitakan bahwa Persis keluar dari persembunyiannya dengan mengadakan muktamar dan mengundang pers. Pemberitaan harian Kompas tersebut kemudian dibalas dengan pernyataan dari PP. Persis bahwa Persis bukan merupakan organisasi yang tertutup, melainkan sebuah organisasi yang terbuka terhadap semua elemen masyarakat yang hendak mengetahuinya. Sikap ini jelas memperlihatkan arah baru perjuangan

HISTORIA: Jurnal Pendidik dan Peneliti Sejarah, p-issn:2620-4789 | e-issn:2615-7993 
yang dimiliki oleh Persis. Isi surat balasan yang ditandatangani oleh Bambang Setyo sebagai ketua bidang garapan penyiaran dan publikasi PP Persis, membantah semua pemberitaan Kompas tersebut (Arsip PP. Persis). Dalam bantahan tersebut dikemukakan beberapa peristiwa penting yang terjadi dalam Persis selama kepemimpinan E. Abdurrahman yang sesugguhnya memiliki dinamika organisasi tersendiri dengan mengadakan beberapa kali musyawarah.

Perkembangan lain dari proses keterbukaan Persis adalah bergabungnya A. Latief Muchtar dengan PPP yang pada saat itu memunculkan kontroversi.. Walaupun tidak menyatakan diri mewakili Persis secara organisasi, namun masuknya A. Latief Muchtar menjadi salah satu Calon Anggota Legislatif PPP telah ikut membawa anggota Persis terlibat dalam politik praktis, bahkan putranya, Ihsan Setiadi Latief yang pada awalnya tidak menyetujui bergabungnya A. Latief Muchtar ke PPP, tapi saat kampanye berlangsung, beliau salah satu anggota Persis yang melaksanakan kampanye tersebut paling depan. Akhirnya melalui Pemilihan Umum tahun 1997, A Latief Muchtar terpilih sebagai salah satu anggota DPR/ MPR Pusat Republik Indonesia. Hal yang menarik dari bergabungnya A. Latief Muchtar dengan PPP adalah pemilihan teman diskusi A. Latief Muchtar dalam menentukan pilihan tersebut. A. Latief Muchtar lebih banyak meminta pendapat dari Anwar Haryono yang bukan tokoh Persis dan juga Rusyad Nurdin yang juga sudah tidak aktif di Persis, padahal dalam tubuh Persis terdapat Dewan Hisbah yang sesungguhnya merupakan tempat khusus pengambil keputusan apapun tentang hukum. Disini terlihat keengganan A. Latief Muchtar untuk mengkomunikasikan keinginan beliau tersebut mengingat anggota Persis yang belum siap menerima keterlibatan Persis dalam politik praktis.

Beberapa kalangan dalam Persis dan juga tulisan-tulisan A. Latief Muchtar memberikan sebuah kejelasan bahwa permikiran A. Latief Muchtar sangat terbuka dengan segala pemikiran yang berkembang. Dicantumkannya mata kuliah Filsafat dan Tasawwuf pada Perguruan Tinggi milik Persis telah menguatkan pemikirannya yang terbuka. Sebelum pencantuman tersebut, beberapa kalangan dalam Persis sangat tabu dengan ajaran
Filsafat dan Tasawwuf karena dianggap tidak berasal dari Quran dan Sunnah, tetapi dengan penyampaian yang sederhana, A. Latief Muchtar berhasil memberikan argumentasi kepada seluruh anggota Persis sehingga saat ini justru banyak lulusan dari Pesantren Persis yang masuk ke jurusan Aqidah Filsafat IAIN.

Perkembangan pemikiran Persis, A. Latief Muchtar benahi dan perbaharui dengan mengenalkan dunia Tasawwuf dan Filsafat yang dijadikan kurikulum di STAIPI, padahal sebelumnya kedua materi tersebut sangat dilarang dalam Persis (Nurmalasari, 1998 : 41). Pengenalan A. Latief Muchtar dengan pasca sarjana IAIN Syarif Hidayatullah Jakarta yang memberikan mata kuliah Filsafat dan Tasawwuf telah mempengaruhi pola fikir A. Latief Muchtar dan juga Persis secara keseluruhan. Tasawwuf dan Filsafat yang bagi kalangan Persis merupakan suatu ilmu yang bisa mengacaukan fikiran seseorang, kini justru dipelajari oleh para santri lulusan pesantren Persis. Pengenalan generasi muda Persis terhadap Tasawwuf dan Filsafat akhirnya telah ikut membantu penyebaran pemikiran yang lebih moderat dalam tubuh Persis, khususnya generasi muda. Dalam pandangan penulis, akibat riil dari proses di atas adalah munculnya pemikiran-pemikiran baru dalam tubuh generasi muda Persis, sekalipun intensitasnya tidak sebesar perkembangan Islam liberal Indonesia saat ini.

Para santri yang masuk ke IAIN ataupun ke STAIPI dan memilih jurusan Aqidah Filsafat terkadang dianggap aneh oleh kalangan Persis karena pemikirannya yang tidak sejalan dengan alur pemikiran kalangan Persis. bahkan para santri banyak yang mengkritik proses pembelajaran mereka ketika di Tsanawiyyah dan Muallimin Persis yang dianggapnya terlalu doktriner. aturan-aturan pengambilan hukum tokoh Persis sebelumnya tidak lagi dijadikan satu-satunya patokan untuk pengambilan hukum dan cara berfikir kalangan Persis, baik yang secara langsung menyatakan anggota Persis maupun simpatisan.

Perkembangan tersebut secara faktual merupakan bagian dari pengaruh pemikiran dari A. Latief Muchtar terhadap sikap politik Persis selanjutnya. Proses keterbukaan yang menjadi pemikiran awal A. Latief Muchtar dalam Persis telah 
memberikan hasil. Kini anggota Persis sudah sangat terbuka dengan perkembangan apapun, jamaah Persis tidak tabu lagi untuk terlibat secara langsung dalam politik praktis, padahal sebelumnya mereka seolah-olah malu-malu berekspresi dalam politik (Latief : 30/05/2005).

Akibat lain dari proses keterbukaan yang diusung oleh A. Latief Muchtar berpengaruh terhadap jumlah kader Persis. Berikut adalah perkembangan jumlah kader sebelum dan sesudah kepemimpinan A. Latief Muchtar yang diambil dari laporan pertanggung jawaban A. Latief Muchtar :

Tabel 4.1. Jumlah Anggota Persis tahun 1990 Kepengurusan A. Latief Muchtar periode 1983-1990

\begin{tabular}{|l|c|c|}
\hline N0 & Cabang & Banyaknya Anggota \\
\hline 1964 & 63 & 7.173 \\
\hline 1967 & 56 & 4.455 \\
\hline 1980 & 81 & 3.717 \\
\hline 1990 & 97 & 7.306 \\
\hline
\end{tabular}

Perkembangan di atas memperlihatkan peningkatan jumlah anggota yang sangat signifikan sebagai akibat dari keterbukaan. Jika pada tahun 1964, 1967 dan tahun 1980 keanggotaan Persis justru menurun karena Persis lebih berkonsentrasi secara internal, maka pada tahun 1990, tujuh tahun setelah A. Latief Muchtar menjadi ketua umum Persis, jumlah anggota Persis kembali ke semula, bahkan terdapat tambahan keanggotaan. Pada masa kepengurusan berikutnya jumlah tersebut semakin besar, terutama penjumlahan dalam perluasan Pimpinan Daerah :

Tabel 4.2. Jumlah Anggota Persis tahun 1995

\begin{tabular}{|c|c|l|l|c|}
\hline No & Tahun & $\begin{array}{c}\text { Jumlah } \\
\text { Pimpinan } \\
\text { Daerah }\end{array}$ & $\begin{array}{c}\text { Jumlah } \\
\text { Pimpinan } \\
\text { Cabang }\end{array}$ & $\begin{array}{c}\text { Jumlah } \\
\text { Anggota }\end{array}$ \\
\hline 1 & 1964 & - & 63 & 7.173 orang \\
\hline 2 & 1967 & - & 56 & 4.455 orang \\
\hline 3 & 1980 & 3 & 81 & 3.717 orang \\
\hline 4 & 1990 & 8 & 96 & 7.306 orang \\
\hline 5 & 1995 & 24 & 184 & - \\
\hline
\end{tabular}

Sumber : Laporan Pertanggung Jawaban Persis Kepengurusan A. Latief Muchtar periode 1990-1995

Perkembangan paling besar terjadi pada peningkatan jumlah Pimpinan Daerah (PD) yang mencapai $200 \%$ dengan jumlah anggota yang tidak tercantum. Perkembangan ini telah menempatkan Persis sebagai salah satu organisasi dengan cakupan nasional. Wildan (1997: 147) memberikan jumlah yang lebih banyak. Pada tahun 1995, Persis memiliki 196 Pimpinan Cabang, 26 Pimpinan Daerah, tiga Pimpinan Wilayah dengan 10.604 yang tersebar di 14 propinsi.

Bila perkembangan yang terjadi dalam tubuh Persis dihubungkan dengan pemikiran A. Latief Muchtar, maka terdapat relevansi yang sangat terlihat. Sebagai seorang ketua, A Latief Muchtar memiliki posisi tersendiri untuk memberikan arah perjuangan Persis. Pilihan keterbukaan yang menjadi ciri khas Persis di bawah kepemimpinan A. Latief Muchtar bukan sekedar tuntutan politis maupun sosiologis karena pemerintah yang refresif tetapi merupakan bagian yang tidak terpisahan dari implikasi pemikiran yang dimiliki oleh A. Latief Muchtar. Hal ini diperkuat oleh pendapat Aminullah (05/06/2005) dan Sastranegara (04/04/2005) yang menyatakan bahwa tanpa adanya sikap arif dan bijaksana yang dimunculkan oleh A. Latief Muchtar, maka Persis yang sering berada dalam tekanan, baik itu dari anggota maupun pemerintahan tidak akan mampu melewatinya dengan baik. Kebijakankebijakan yang telah dikeluarkan oleh A. Latief Muchtar tidak akan terlepas dari pemikiran yang beliau miliki.

Menurut Latief (30/05/2005) hal yang menjadi keberhasilan A. Latief Muchtar terletak pada upaya membuka pintu Persis selebar-lebarnya dengan segala potensi dakwah yang tersedia selain juga harus menanggung konsekuensi yang akan terjadi. Keterbukaan yang telah digulirkan oleh A. Latief Muchtar akhirnya telah membawa perubahan mendasar pada sikap politik Persis. Sikap politik yang isolatif pada masa E. Abdurrahman menjadi sebuah pemikiran ulang tentang keberadaan Persis. hal ini mengakibatkan perubahan dalam segala bidang yang terjadi dalam tubuh Persis, baik dalam pemikiran, pengambilan hukum dan kehidupan sosial anggota Persis.

Menurut Qadir (1998, xxiii) salah seorang keturunan A. Hassan, memberikan pendapat tentang perkembangan Persis dan A. Latief Muchtar:

"Beliau tidak hanya dikenal oleh masyarakat

Persis, tetapi juga oleh pemerintah. Kalangan 
pemerintah bahkan mengenal baik sepak terjang almarhum, sehingga membawa citra yang baik terhadap perkembangan Persis secara makro : Persis yang sebelumnya dikenal sebagai ekslusif menjadi inklusif".

Terobosan-terobosan yang dilakukan A. Latief Muchtar sehingga menampilkan cita baru Persis yang diakui eksistensinya oleh berbagai kalangan telah menimbulkan reaksi beragam dari kalangan Persis. Sebagian kalangan Persis memberikan pertanyaan, misalnya mau dibawa kemana Persis ini ? apakah organisasi Persis ini masih seperti dulu ?. Tentang sikap politik A. Latief Muchtar yang kontroversial, terlepas dari pro dan kontra, menurut Latief (1998, L) A. Latief Muchtar telah membuka pintu politik dan juga pintu-pintu yang lainnya agar warga Persis tercerahkan atau minimal diingatkan bahwa mengambil sikap itu adalah sebuah keharusan. Reaksi yang ditimbulkan oleh para anggota Persis dalam menanggapi segala persoalan yang menyangkut Persis dan perkembangan politik merupakan kemajuan tersendiri sebagai budaya keterbukaan yang mulai terbangun.

Sikap politik Persis yang terbuka terhadap pemerintah, untuk kemudian diakui oleh kalangan birokrat. Dalam sebuah obrolan dengan Zuhal Abdul Qadir, salah seorang cucu A. Hassan yang pernah menjadi mentri pada masa pemerintahan B. J. Habibie mengatakan bahwa "Persis merupakan suatu kekuatan besar, karena mereka mampu melahirkan kader-kader berkaliber nasional dan internasional, seperti pak Natsir" (Qadir, 1998: xxiv).

Begitulah pemikiran A. Latief Muchtar secara pemikiran dan kepemimpinannya telah membawa warga Persis ke arah yang baru. Persis menjadi sebuah organisasi yang terbuka terhadap segala kemungkinan yang terjadi. Seluruh perkembangan yang terjadi merupakan bagian dari persoalan yang juga diurus kalangan Persis. Hal ini dibuktikan dengan pernyataan-pernyataan yang dikeluarkan Persis sehubungan dengan perkembangan dunia Islam, baik bersifat nasional maupun internasional. Pada saat terjadi tragedi Bosnia, A. Latief muchtar sebagai ketua umum PP Persis menghimbau kepada seluruh anggota Persis untuk melakukan Qunut Nazilah sebagai bentuk solidaritas (Risalah No. 9

\section{Th. XXXV Nopember 1997 : 20).}

Bila hendak menganalisis, seluruh keterbukaan yang dimiliki oleh Persis sejak A. Latief Muchtar menjadi ketua umum Persis sampai beliau wafat sesungguhnya memiliki keterhubungan dengan pemikiran A. Latief Muchtar sekalipun masih terdapat faktor lain yang menyebabkannya. Perubahan politik Persis tersebut, juga didukung oleh perubahan sikap politik Orde Baru pada tahun 90-an. Soeharto yang terkenal sebagai pembela setia kejawen dan pluralisme Pancasila, kini telah benar-benar memberikan beberapa konsesi kepada ummat Islam. Hal ini secara nyata terlihat dari dibentuknya sebuah organisasi bagi golongan menengah Islam Indonesia dengan nama Ikatan Cendekiawan Muslim Indonesia (ICMI) (Hefner, 2001 :225). Sikap politik Soeharto yang memberikan sikap berbeda setelah tahun 1990-an memberikan kesempatan kepada Persis di bawah kepemimpinan A. Latief Muchtar untuk menyampaikan konsepsi tentang Islam ideal yang keterhubungannya dengan perkembangan politik Indonesia. Dalam salah satu ceramah shalat Jumat tanggal 22 Agustus 1997, A. Latief Muchtar berkata :

"Hadirin yang berbahagia.

Jadi kebebasan kelompok, kebebasan golongan, kemerdekaan individu itu ditanamkan dalam Islam sepanjang tidak melakukan kekacauan.

Bangsa yang besar adalah yang menghormati kebebasan, kemerdekaan. Dan suatu bangsa akan mundur bila kurang inisiatif, tidak ada kemampuan kompetitif. Itu barangkali karena kurang kebebasan.

Hadirin yang berbahagia

Sudah banyak contoh negara sosialis hancur karena kebebasan individu dan kelompok sangat dibatasi. Kritik penguasa seolah peka. Pejabat-pejabat seolah maksum padahal manusia ada saja kekuarangannya. Bagi kaum muslimin memiliki kewajiban watawasau bil haq watawasau bi sabr

Maka mudah-mudahan dalam era sekarang ini pemerintah mengoptimalkan kebebasan itu dalam rangka membangun bangsa yang sedang berkembang ini. Mudah-mudahan kita diberi hidayah dan taufiq oleh Allah sehingga tidak terjadi paradok antara nilai-nilai yang universal

HISTORIA: Jurnal Pendidik dan Peneliti Sejarah, p-issn:2620-4789 | e-issn:2615-7993 
dengan praktek yang kita laksanakan (Muchtar: 1997)".

Sikap terbuka Persis di bawah kepemimpinan dan pemikiran A. Latief Muchtar bertemu dengan kebijakan baru pemerintah Orde Baru yang tidak lagi memusuhi Islam. Hal ini sangat berpengaruh terhadap keberadaan Persis di tengah-tengah ummat Islam Indonesia. Selama kepemimpinan A. Latief Muchtar, sikap politik Persis relatif berubah. Sikap politik disini maksudnya bukan hanya sekedar aktifitas politik secara konkrit melainkan semua sikap yang telah menjadi kebijakan Persis dalam menghadapi semua kemungkinan yang berkembang dalam perkembangan politik Indonesia dan dunia.

\section{KESIMPULAN}

A. Latief Muchtar hidup dalam lingkungan pedagang yang membesarkannya dengan pendekatan moderat dan dialogis. Pengalaman A. Latief Muchtar sebagai seorang anak pedagang dan kemudian dikuatkan dengan proses pendidikan Pesantren Persis dan sekolah formal dalam dan luar negeri sampai jenjang S3 di IAIN Syarif Hidayatullah Jakarta telah membentuk pemikiran A. Latief Muchtar yang berimbang antara pemikiran tradisionalisme pesantren, pemikiran barat sekolah formal pemerintah, pemikiran tekstualisme Timur Tengah dan rasionalisme IAIN Syarif Hidayatullah. Interaksi luas dengan berbagai kalangan yang dilakukan A. Latief Muchtar juga telah memberikan pengaruh terhadap pemikiran beliau yang tidak statis dan selalu menyesuaikan dengan perkembangan zaman tanpa harus melepas batasan-batasan syar'i yang telah disepakati para tokoh Persis. Pengalaman perjalanan hidup A. Latief Muchtar tersebut telah memberikan warna lain dalam corak pemikiran dan kepemimpinanya di Persis.

Pemikiran A. Latief Muchtar memiliki cakupan yang cukup luas. Seluruh aspek dalam kehidupan menjadi pemikiran A. Latief Muchtar, baik itu sosial, politik, sejarah, ekonomi, pendidikan, dan juga bidang agama yang menjadi fokus akademiknya. Hal ini terjadi disebabkan oleh posisi beliau sebagai seorang tokoh salah satu organisasi keagamaan yang mengharuskannya memikirkan permasalahan ummat secara holistik. Kajian yang dibahas oleh organisasi keagamaan seperti Persis sekalipun memiliki ciri khas, namun selalu membahas semua yang menjadi permasalahan ummat sebagai tanggung jawab pemberi peringatan. Tidak jarang pemikiran A. Latief Muchtar mengemuka tatkala timbul gejolak masyarakat yang mengharuskan ia memberikan pemikirannya sebagai pemberian status hukum terhadap suatu fenomena yang terjadi di masyarakat.

Secara keseluruhan, Pemikiran A. Latief Muchtar memiliki karakteristik moderat. Kesan Persis sebelum kepemimpinan A. Latief Muchtar yang sangat tegas dalam berdakwah, diganti dengan format dakwah A. Latief Muchtar yang fleksibel dan persuasif. Pendekatan moderat ini juga terlihat dari cara pengambilan keputusan hukum A. Latief Muchtar yang sedikit berbeda dengan tokoh Persis lainnya. Hal ini pada akhirnya mempengaruhi sikap politik Persis yang menerima Pancasila sebagai asas organisasi, mendukung beberapa kebijakan pemerintah, dan masuknya kembali para anggota Persis dalam dunia politik setelah A. Latief Muchtar menaytakan diri menjadi calon anggota legislatif dari PPP dan hal-hal lainnya.

A. Latief Muchtar tidak banyak memiliki pemikiran orisinal. Pemikiran A. Latief Muchtar secara keseluruhan banyak diambil dari pemikiran tokoh lain. Hal ini merupakan sebuah keharusan beliau sebagai seorang akademisi yang harus mencantumkan referensi kajian. Pemikiran A. Latief Muchtar yang merupakan buah fikirnya sendiri hanya berkaitan dengan Persis dan segala sesuatu yang berhubungan dengan pengalamannya dalam memimpin Persis. Pemikiran fiqh A. Latief Muchtar misalnya banyak dipengaruhi oleh Yusuf Qardlawi sedangkan pemikiran sejarah banyak dipengaruhi oleh Ibnu Khaldun. Pemikiran-pemikiran lainnya juga A. Latief Muchtar sering mengutip tokoh lain.

Pemikiran A. Latief Muchtar merupakan sebuah refleksi tentang kehidupan politik yang dibangun oleh Orde Baru. sebagia besar pemikiran A. Latief Muchtar memiliki tujuan yang jelas yakni pemerintah dan semua pihak yang telah menjalankan kehidupan berbangsa dan bernegara tanpa memperhatikan rambu-rambu Islam untuk 
mengaturnya.

Bila dibandingkan dengan tokoh-tokoh Persis sebelumnya, A. Latief Muchtar memiliki pemikiran yang berbeda. A. Hassan sama sekali tidak menerima qias sebagai sebuah bentuk pengambilan keputusan hukum dalam Islam, tetapi A. Latief Muchtar memasukan qias sebagai salah satu cara pengambulan keputusan hukum dalam Islam meskipun dalam bidang fiqh ibadah. Tokoh-tokoh Persis lainnya sangat jarang mengungkapkan tentang aspek lain selain fiqh ibadah dan politik, tetapi A. Latief Muchtar memikirkan semua permasalahan yang muncul seperti perekonomian, ide perguruan tinggi, kajian Filsafat, kajian Tasawwuf, asuransi dan lain sebagainya.

Pemikiran A. Latief Muchtar tersebut telah memberikan pengaruh terhadap sikap politik Persis yang pada saat sebelum kepemimpinan A. Latief Muchtar terkesan menutup diri dengan isolasi strategi yang dikembangkan K.H.E. Abdurrahman. Kepemimpinan A. Latief Muchtar telah membawa Persis ke era keterbukaan. Proses keterbukaan tersebut ditandai dengan penerimaan terhadap asas tunggal Pancasila, kerjasama terhadap pemerintah, dimasukannya mata kuliah Filsafat dan Ilmu Tasawwuf pada Perguruan Tinggi Persis, bergabungnya Persis dalam beberapa lembaga bentukan pemerintah, keikut sertaan anggota Persis dalam pemilu 1997 yang menempatkan A. Latief Muchtar sebagai Anggota DPR/MPR untuk daerah pemilihan Jawa Barat, dan bertambahnya jumlah Pimpinan Daerah, Pimpinan Cabang dan anggota Persis, berkembangnya arus pemikiran baru di kalangan generasi muda Persis serta halhal lainnya. Argumentasi-argumentasi di atas telah membuktikan bahwa pemikiran A. Latief Muchtar telah mampu secara berangsur-angsur mengubah sikap politik Persis berkenaan dengan perkembangan Indonesia serbagai sebuah negara.

Pada sebagainya.

\section{REFERENSI}

Alimurrohman. (1998). "Kontribusi Pemikiran K.H. Latief Muchtar MA. Tentang Pembangunan Perekonomian Ummat Dalam Program Kerja Persis Tahun 1995-1997”. Penelitian Tidak Diterbitkan. Jurusan Perbandingan Agama
Fakultas Ushuludin IAIN Sunan Gunung Djati. Anshary, Isa. (1958). Manifes Perdjuangan Persatuan Islam. Bandung : Pusat Pimpinan Persatuan Islam.

Budiarjo, Miriam. (1994). Demokrasi Di Indonesia; Demokrasi Parlementer dan demokrasi Pancasila. Jakarta : Gramedia Pustaka Utama.

Cuanda, Cucu dan Miftah Fauzi Rakhmat. [eds.]. (1998). Gerakan Kembali Ke Islam-Warisan Terakhir A. Latief Muchtar Ketua Umum Persis 1983-1997. Bandung : Rosda Karya.

Departemen Agama Republik Indonesia. (1994). Al-Quran Dan Terjemahnya. Semarang : PT Kumudasmoro Grafindo.

Fatah, Eep Saefullah. (2000). Pengkhianatan Demokrasi Ala Orde Baru Masalah Dan Masa Depan Demokrasi Terpimpin Konstitusional. Bandung : Rosda.

Fiederspiel, Howard M.. (1996). Persatuan Islam: Pembaharuan Islam Indonesia Abad XX. Yogyakarta : University Press.

Gottschalk, Louis. (1986). Mengerti Sejarah. Terjemahan. Jakarta : Penerbit Universitas Indonesia.

Hariyono. (1995). Mempelajari Sejarah Secara Efektif. Jakarta : Dunia Pustaka Jaya.

Haryono, Anwar. (1997). "K.H. Abdul Latief Muchtar : Ulama yang Tawadlu dan Pemimpin yang Gigih" dalam Cucu Cuanda dan Miftah Fauzi Rakhmat [eds.] Gerakan Kembali Ke Islam-Warisan Terakhir A. Latief Muchtar Ketua Umum Persis 1983-1997. Bandung : Rosda Karya.

Hermawan, Dadang. (1999). "Peran Politik Persatuan Islam Pada Tiga Corak Demokrasi di Indonesia”. Penelitian Tidak Diterbitkan. Fakultas Ilmu Sosial Dan Ilmu Politik, Universitas Padjadjaran. Kuntowijoyo. (2002). Selamat Tinggal Mitos Selamat Datang Realitas-Esai-esai Budaya Dan Politik. Bandung : Mizan Media Utama.

Kuntowijoyo. (2003). Metodologi Sejarah. Yogyakarta : Tiara Wacana.

Latief, Ihsan S. (1998). "Meretas Jalan Membuka Pintu-pintu Kemungkinan" dalam Cucu Cuanda dan Miftah Fauzi Rakhmat [eds.]. Gerakan Kembali Ke Islam-Warisan Terakhir A. Latief Muchtar Ketua Umum Persis 1983-1997.

HISTORIA: Jurnal Pendidik dan Peneliti Sejarah, p-issn:2620-4789 | e-issn:2615-7993 
Bandung : Rosda Karya.

Luth, Tohir. (1999). M. Natsir Dakwah Dan Pemikirannya, Bandung : Gema Insani Press.

Moleong, Lexy J. (1998). Metodologi Penelitian Kualitatif. Terjemahan. Bandung : Remaja Rosda Karya.

Muchtar, A. Latief. (1995). “Al-Quran dan Realita Sosial". Makalah disajikan dalam Pelatihan Dosen Pendidikan Agama Islam Perguruan Tinggi Umum Se Indonesia di IKIP Bandung : t.p.

Muchtar, A. Latief. (1992). "Hadits Sebagai Sumber Ajaran Islam-Tinjauan Ontologis dan Epistimologis", Makalah disajikan dalam Seminar Nasional Pengembangan Pemikiran Terhadap Hadits di Universitas Muhammadiyyah Yogyakarta : t.p.

Muchtar, A. Latief. (1997). "Paradoks Kemerdekaan", Khutbah Jumat disajikan tanggal 22 Agustus. Bandung : t.p.

Muchtar, A. Latief. (1994). “Tantangan Masa Kini dan Masa Depan”. Ceramah disajikan dalam khutbah Idul Fitri di Pajagalan No. 14 Bandung :t.p.

Muchtar, A. Latief. (1986). "Suri Tauladan". Ceramah disajikan dalam Khutbah Idul Fitri di Lengkong Besar 105 Bandung : t.p.

Muchtar, A. Latief. (1985). "Radikalisme Dalam Islam" dalam Risalah No 11 Th XXII. Bandung.

Muchtar, A. Latief. (1984). "Masjid dan Negara" dalam Risalah No. 9 tahun XXII. Bandung, Desember

Muchtar, A. Latief. (1987). "A. Hassan Tokoh Perdebatan Agama" dalam Risalah No 2 th XXV, Bandung.

Muchtar, A. Latief. (1986). "Berhasil Pembangunan Ekonomi Gagal Pembanguan Sosial" dalam Risalah No. 7 Th. XXIV. Bandung.

Muchtar, A. Latief. (1984)."Ibadah Haji dan Politik Kolonial" dalam Risalah No. 6 Tahun XXII. Bandung, Agustus

Muchtar, A. Latief. (t.t). "Makna Metodologis Penuturan Al-quran" dalam Risalah No. 8 TH. XXV. Bandung.

Muchtar, A. Latief. (1992). "Pengembangan Pendidikan di Pesantren”. Makalah disajikan dalam Diskusi Panel Sejarah di Pesantren Persis
Benda Tasikmalaya : t.p.

Muchtar, A. Latief. (1990). "Jihad". Ceramah. Bandung : t.p.

Muchtar, A. Latief. (1989). “Al-Imamah". Artikel. Bandung : t.p.

Muchtar, A. Latief. (1985). "Kompilasi Dan Kodifikasi Hukum Islam dalam Konteks PerundangUndangan di Indonesia”. Makalah. Bandung : t.p.

Muchtar, A. Latief. (1995). "Tujuan Pendidikan Islam Dan Tujuan Pendidikan Nasional”. Makalah. Bandung : t.p.

Muchtar, A. Latief. (1995)."Peran, Fungsi Dan kontribusi Pendidikan Persatuan Islam Dalam Era Globalisasi ". Makalah disajikan dalam Semiloka di Tasikmalaya : t.p.

Muchtar, A. Latief. (1996). "Ulama dan Pembangunan”. Makalah. Bandung : t.p.

Muchtar, A. Latief. (t.t.) "Uraian Teori ijtihad". Makalah. Bandung : t.p.

Muchtar, A. Latief. (t.t.) "Metode Tafsir al-Quran". Makalah. Bandung : t.p.

Muchtar, A. Latief. (1990). "Laporan Pertanggung Jawaban Pimpinan Pusat Persatuan Islam masa jihad 1983-1990". Garut : t.p.

Muchtar, A. Latief. (1990). "Laporan Pertanggung Jawaban Pimpinan Pusat Persatuan Islam masa jihad 1990-1995". Jakarta : t.p.

Muhammad, Afif (1997). "Ustadz Latief Muchtar : Upaya Menarik Sebuah Garis" dalam Cucu Cuanda dan Miftah Fauzi Rakhmat [eds.]. Gerakan Kembali Ke Islam-Warisan Terakhir A. Latief Muchtar Ketua Umum Persis 1983-1997. Bandung : Rosda Karya.

Nurdin, Rusyad. (1998) "Mengenal Ustad K.H. Abdul Latief, M.A." dalam Cucu Cuanda dan Miftah Fauzi Rakhmat [eds.] Gerakan Kembali Ke Islam-Warisan Terakhir A. Latief Muchtar Ketua Umum Persis 1983-1997. Bandung : Rosda Karya.

Nurmalasari, Siti I. (1998). "Respon Pemerintah Orde Baru Terhadap Aspirasi Sosial Keagamaan Ummat Islam (1966-1994)", Penelitian Tidak Diterbitkan. Bandung : Jurusan Kebudayaan Islam Fakultas Adab IAIN Sunan Gunung Djati Bandung.

Noer, Deliar. (1994). Gerakan Modern Islam Di 
Indonesia 1900-1942, Jakarta : LP3ES.

Panitia Muktamar Persatuan Islam. (1995). "Hasilhasil Muktamar XI Persatuan Islam (Persis)”. Jakarta : Panitia Muktamar Persatuan Islam.

PP Persatuan Islam. (1987). Qanun Asasi dan Qanun Dakhili Persatuan Islam (Persis). Bandung : PP Persatuan Islam.

PP Persatuan Islam. (1991). Qanun Asasi dan Qanun Dakhili Persatuan Islam (Persis). Bandung : PP Persatuan Islam.

Qadir, Zuhal Abdul (1998). "Pak Muchtar Seorang Pemimpin yang Mempunyai Visi ke Depan" dalam Cucu Cuanda dan Miftah Fauzi Rakhmat [eds.]. Gerakan Kembali Ke Islam-Warisan Terakhir A. Latief Muchtar Ketua Umum Persis 1983-1997. Bandung : Rosda Karya.

Qardlawi, Yusuf. (1999). Fiqih Daulah Dalam Perspektif Al-Quran Dan As-Sunnah. Terjemahan. Jakarta : Pustaka Al-Kautsar.

Rahman, M Taufik. (1999). “A Revivalist Response To Modernity (A. Latief Muchtar [1931-1997] Of The Persatuan Islam In Indonesia's New Order)". Tesis. Tidak Diterbitkan. Leiden : The Faculty Of Theology and The Faculty Of Arts Leiden University.

Rais, M. Amin. (1998). "Gelombang dan Frekwensinya Sama dengan Muhammadiyah" dalam Cucu Cuanda dan Miftah Fauzi Rakhmat [eds.] Gerakan Kembali Ke Islam-Warisan Terakhir A. Latief Muchtar Ketua Umum Persis 1983-1997. Bandung : Rosda Karya.

Rakhmat, Jalaluddin (1998) "Ustadz Latief: Pembaru yang Sederhana" dalam Cucu Cuanda dan Miftah Fauzi Rakhmat [eds.] Gerakan Kembali Ke Islam-Warisan Terakhir A. Latief Muchtar Ketua Umum Persis 1983-1997. Bandung : Rosda Karya.

Ricklefts, M.C. (1998). Sejarah Indonesia Modern, Terjemahan. Yogyakarta : Gadjah Mada University Press.

Sanit, Arbi. (1995). Ormas Dan Politik. Jakarta : Lembaga Studi Informasi Pembangunan (LSIP). Sjamsuddin, Helius. (1996). Metodologi Sejarah.
Jakarta : Departemen P dan K Birektorat Dikti. Proyek Tenaga Akademik.

Stoddard, Lothrof. (1966). Dunia Baru Islam, Terjemahan. Djakarta : Panitia Penerbit.

Taher, Tarmizi. (1998). "Kesan Saya terhadap K.H. Latief Muchtar" dalam Cucu Cuanda dan Miftah Fauzi Rakhmat [eds.]. Gerakan Kembali Ke Islam-Warisan Terakhir A. Latief Muchtar Ketua Umum Persis 1983-1997. Bandung : Rosda Karya.

Wildan, Dadan. (1997). Yang Da'i Yang PolitikusHayat Dan Perjuangan Lima Tokoh Persis. Bandung : Remaja Rosda Karya.

Wildan, Dadan. (1995). Sejarah Perjuangan Persis 1923-1983. Bandung: Gema Syahida.

Wildan, Dadan. (2000). Pasang Surut Gerakan Pembaharuan Islam Di Indonesia-Potret Perjalanan Sejarah Organisasi Persatuan Islam (Persis). Bandung : Persis Press.

Yatim, Badri. (1997). Historiografi Islam, Jakarta : Logos Wacana Ilmu.

Majalah :

Risalah No. 9 TH XXII, Rabi'ul Awwal 1405 H/ Desember $1984 \mathrm{M}$

Risalah No. 11 TH XXII, Jumadil Ula 1405 H/ Februari $1985 \mathrm{M}$

Risalah No. 7 TH XXIV, Muharram 1407-Shafar 1407 H/VIII-1986

Risalah No. 5 TH. XXXI, Rabi'ul Awwal 1414 H/ September $1993 \mathrm{M}$

Risalah No. 6 TH. XXXIII, Rabi'ul Awwal 1416 H/ Agustus $1995 \mathrm{M}$

Risalah No. 7 TH. XXXIII, Rabi'ul Tsani1416 H/ September $1995 \mathrm{M}$

Risalah No. 8 TH. XXXIII, Jumadil Ula 1416 H/ Oktober $1995 \mathrm{M}$

Risalah No. 9 TH. XXXV, Rajab 1418 H/ Nopember $1997 \mathrm{M}$ 